Portland State University

PDXScholar

Fall 8-15-2012

\title{
Investigating the Holocene History of Eliot Glacier, Mount Hood, Oregon
}

Nadia Sittara Jones

Portland State University

Follow this and additional works at: https://pdxscholar.library.pdx.edu/open_access_etds

Part of the Geography Commons, and the Glaciology Commons Let us know how access to this document benefits you.

\section{Recommended Citation}

Jones, Nadia Sittara, "Investigating the Holocene History of Eliot Glacier, Mount Hood, Oregon" (2012). Dissertations and Theses. Paper 618.

https://doi.org/10.15760/etd.618

This Thesis is brought to you for free and open access. It has been accepted for inclusion in Dissertations and Theses by an authorized administrator of PDXScholar. Please contact us if we can make this document more accessible: pdxscholar@pdx.edu. 
Investigating the Holocene History of Eliot Glacier, Mount Hood, Oregon

by

Nadia Sittara Jones

A thesis submitted in partial fulfillment of the

requirements for the degree of

Master of Science

in

Geography

Thesis Committee:

Martin Lafrenz, Chair

Keith Hadley

Scott Burns

Portland State University

2012 
(C) 2012 Nadia Sittara Jones 


\begin{abstract}
This research documents the Holocene glacial history of Mount Hood, Cascade Mountains, Oregon by analyzing a set of three lateral moraines abutting Eliot Glacier, the largest glacier on the mountain. This study seeks to: 1) establish the relative ages of these lateral moraines and 2) determine if these features represent distinct glacial advances. The hypothesis is that the lateral moraines for Eliot Glacier represent three distinct periods of glacial advance based on their position relative to the current glacier and other diagnostic indicators. Soil profiles of three positions (shoulder, backslope, and footslope) on the distal side of each lateral moraine were described in the field and samples were taken from each horizon for laboratory analyses of $\mathrm{pH}$ and particle size. The results of the soil analysis show that the soils developing on the moraine closest to the current glacier are poorly developed and significantly younger than the other two features. The closest moraine likely dates to the Little Ice Age (600-150 YBP) and has soils with an A/C profile and a classification of Andic Cryopsamment. The soils on the middle and furthest moraines from the glacier are similar in the profile sequence (Andic Haplocryepts). Silt bulges were noted in the mid-slope pits. The furthest moraine has deeper horizons and more color development than the middle moraine. Ash layers were found in the backslope soil profile $(36-51 \mathrm{~cm}$ deep) on the middle moraine. Additional lab testing confirms the ash layers originated from Mount Hood, but no date can be assigned. The eruptive history of Mount Hood points to the Timberline eruptive period
\end{abstract}


(1,500 YBP) as a likely candidate for one of the ash deposits. This evidence suggests the middle moraine was actively forming during this period and is intermediate in age between the furthest moraine and the Little Ice Age Moraine; hence, this sequence of moraines indicates three distinct periods of glacial advance in the Neoglacial. 


\section{Table of Contents}

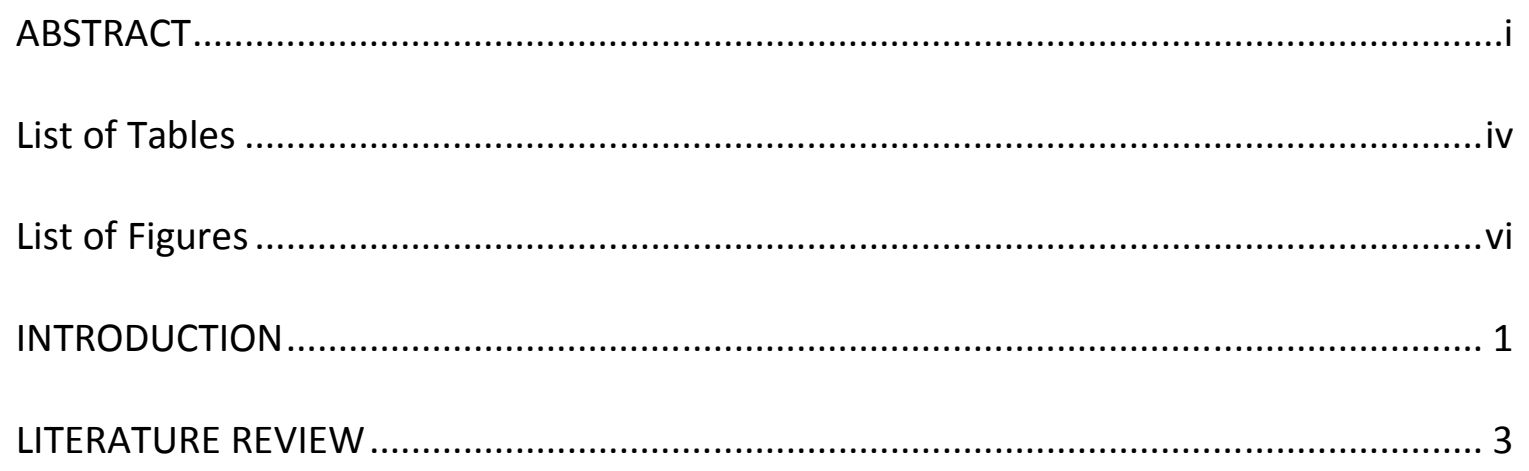

Glacial Advances of the Western United States .................................................................. 3

Mount Hood Geological and Glacial History................................................................. 5

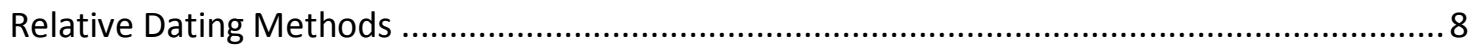

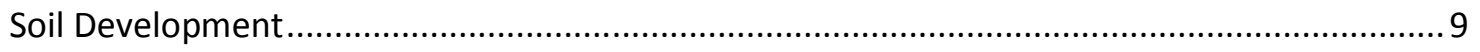

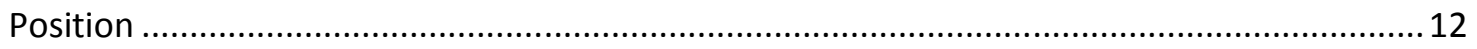

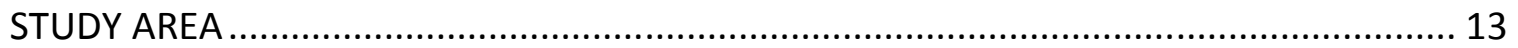

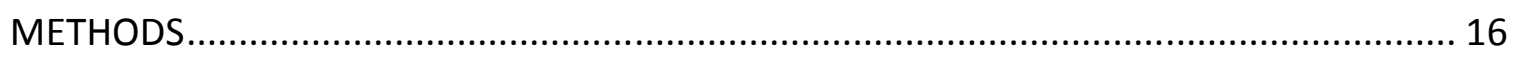

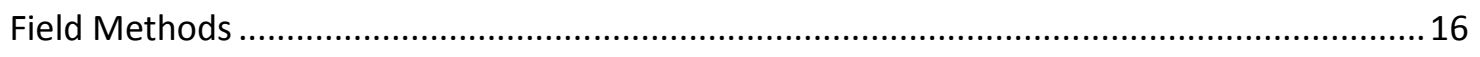

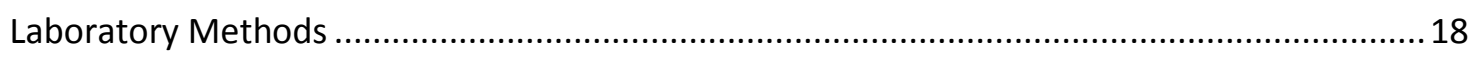

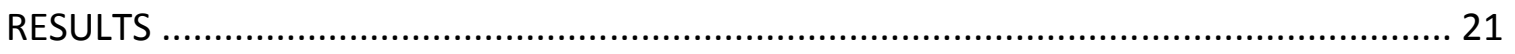

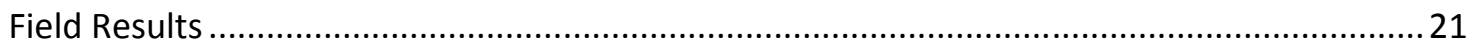

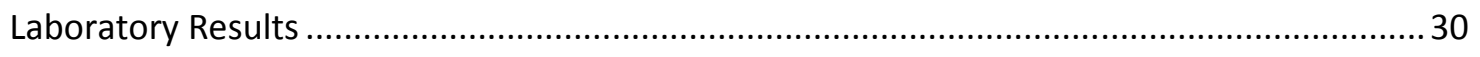

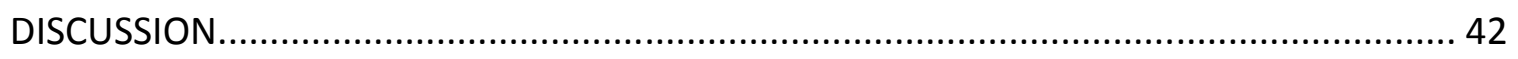

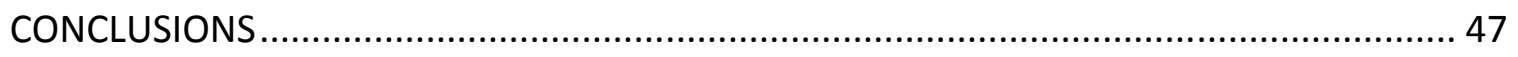

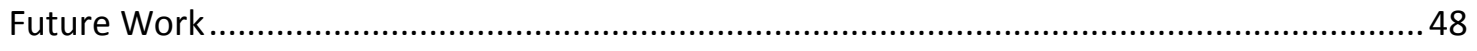

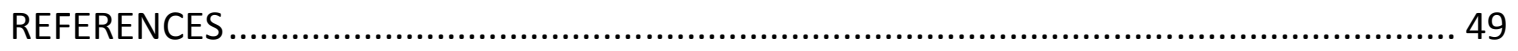




\section{List of Tables}

Table 1: Timing of Holocene Glacial Advances and Mount Hood's Volcanic Activity ........ 7

Table 2: Changes in the Physical Characteristics of Soil with Increased Age ................... 9

Table 3: Field Soil Characteristics of the Shoulder Pit from the O Moraine.................... 22

Table 4: Soil Characteristics of the Backslope Pit from the O Moraine.......................... 22

Table 5: Soil Characteristics of the Footslope Pit from the O Moraine............................ 22

Table 6: Soil Characteristics of the Shoulder Pit from the M Moraine............................ 26

Table 7: Field Soil Characteristics of the Backslope Pit from the M Moraine .................. 26

Table 8: Soil Characteristics of the Footslope Pit from the M Moraine .......................... 26

Table 9: Soil Characteristics of the Shoulder Pit from the LIA Moraine ......................... 29

Table 10: Soil Characteristics of the Backslope Pit from the LIA Moraine ....................... 29

Table 11: Soil Characteristics of the Footslope Pit from the LIA Moraine....................... 29

Table 12: Lab Soil Characteristics of the Shoulder Pit from the O Moraine .................... 31

Table 13: Sand Particle Size Distribution of the Shoulder Pit from the O Moraine ......... 31

Table 14: Lab Soil Characteristics of the Backslope Pit from the O Moraine ................... 32

Table 15: Sand Particle Size Distribution of the Backslope Pit from the O Moraine........ 32 
Table 16: Lab Soil Characteristics of the Footslope Pit from the O Moraine

Table 17: Sand Particle Size Distribution of the Footslope Pit from the O Moraine 33

Table 18: Lab Soil Characteristics of the Shoulder Pit from the M Moraine 35

Table 19: Sand Particle Size Distribution of the Shoulder Pit from the M Moraine 35

Table 20: Lab Soil Characteristics of the Backslope Pit from the M Moraine 36

Table 21: Sand Particle Size Distribution of the Backslope Pit from the M Moraine 36

Table 22: Lab Soil Characteristics of the Footslope Pit from the M Moraine.

Table 23: Sand Particle Size Distribution of the Footslope Pit from the M Moraine 37

Table 24: Lab Soil Characteristics of the Shoulder Pit from the LIA Moraine 39

Table 25: Sand Particle Size Distribution of the Shoulder Pit from the LIA Moraine 39

Table 26: Lab Soil Characteristics of the Backslope Pit from the LIA Moraine 40

Table 27: Sand Particle Size Distribution of the Backslope Pit from the LIA Moraine 40

Table 28: Lab Soil Characteristics of the Footslope Pit from the LIA Moraine 41

Table 29: Sand Particle Size Distribution of the Footslope Pit from the LIA Moraine...... 41

Table 30: Comparison of Climatic Events, Eruptive Periods, and Glacial Features 45 


\section{List of Figures}

Figure 1: Five Position Catena................................................................................11

Figure 2: LiDAR imagery of Mount Hood, Eliot Glacier indicated by red box (USGS) .....14

Figure 3: Eliot Glacier, Mount Hood, OR: Lateral moraines indicated by arrows .15

Figure 4: Close up of study area .17

Figure 5: Photo of the $O$ moraine 21

Figure 6: Photo of shoulder pit on the O moraine. .23

Figure 7: Photo of backslope pit on the O moraine. .23

Figure 8: Photo of footslope pit on the O moraine .23

Figure 9: Photo of shoulder pit on the $\mathrm{M}$ moraine .25

Figure 10: Photo of backslope pit on the $\mathrm{M}$ moraine. .25

Figure 11: Photo of footslope pit on the $\mathrm{M}$ moraine. .25

Figure 12: Photo of vegetation on LIA moraine.

Figure 13: Photo of shoulder pit on the LIA moraine .28

Figure 14: Photo of backslope pit on the LIA moraine .28

Figure 15: Photo of footslope pit on LIA moraine .28 
Figure 16: Particle Size Distribution of the Shoulder Pit from the O Moraine

Figure 17: Particle Size Distribution of the Backslope Pit from the O Moraine 32

Figure 18: Particle Size Distribution of the Footslope Pit from the O Moraine .33

Figure 19: Particle Size Distribution of the Shoulder Pit from the M Moraine .35

Figure 20: Particle Size Distribution of the Backslope Pit from the M Moraine. .36

Figure 21: Particle Size Distribution of the Footslope Pit from the M Moraine .37

Figure 22: Particle Size Distribution of the Shoulder Pit from the LIA Moraine

Figure 23: Particle Size Distribution of the Backslope Pit from the LIA Moraine .40

Figure 24: Particle Size Distribution of the Footslope Pit from the LIA Moraine .41 


\section{INTRODUCTION}

Understanding land formation processes contributes to the overall body of knowledge about the Earth and its history. The study of such long-term processes as pedogenesis and weathering aid in our understanding of rates of land formation and help to explain why landscapes look the way they do. Chronosequence studies focus on the influence of time on these processes and contribute to the understanding of geomorphic processes and landform evolution (Milne, 1935; McFadden and Knuepfer, 1990). This thesis contributes to that understanding by exploring the Holocene history of glacial advances on Mount Hood using relative dating methods on moraine deposits left by Eliot Glacier, the mountain's largest glacier.

Determining the relative age of moraines that parallel Eliot Glacier enriches the existing research on the history of Holocene glaciations on Mount Hood in that it establishes the relative ages of these lateral moraines and assesses if they represent distinct periods of glacial advance. The null hypothesis for this research is that the lateral moraines are close in relative age and do not represent discrete glacial advances. As such these features could be recessional moraines from one glacial episode. The hypothesis presented here is that the lateral moraines for Eliot Glacier represent three distinct periods of glaciation. Relative dating techniques applied to these glacial features are used to assess this hypothesis. 
The study of Holocene glacial advances on Mount Hood also contributes to an understanding of regional past environmental conditions and of possible climate trends. The concept of global synchroneity of glacial events relies on dating deposits and reconstructing a timeline of advance (Benedict, 1973). Currently, the history of Holocene glacial advances in the Rocky Mountains and Sierra Nevada is well studied (Benedict, 1985; Konrad and Clark, 1998), but this history is less well-documented in the Cascade Range. Dating Holocene glacial deposits on Mount Hood increases our knowledge of the timing and extent of the glaciation on this mountain and allows for a more detailed regional comparison. 


\section{LITERATURE REVIEW}

\section{Glacial Advances of the Western United States}

Neoglacial advances across the Western United States have been investigated in the Rocky Mountains, Sierra Nevada, the Cascade Arc from California to Washington, and other isolated alpine areas such as the Wallowas. The Rocky Mountains experienced three distinct Neoglacial periods including the Little Ice Age (600-150 YBP), and two earlier advances at 2,500-950 YBP and 5,000 - 3,500 YBP (Benedict, 1973, 1981, 1985; Davis, 1982, 1988; Davis and Waterman, 1979; Dahms, 2002). These dates were established using relative dating methods, radiocarbon dating, and, cosmogenic radionuclide dating (Dahms et al., 2010). Glacial features dating to the end of the Younger Dryas (12,500 - 11,500 YBP) are associated with the end of the Pleistocene (2.5 million - around $12,000 \mathrm{YBP})$ as opposed to early Holocene $(12,000 \mathrm{YBP}$ - present) in age (Davis, 1988).

The Sierra Nevada Mountains also experienced three Neoglacial periods including during the Little Ice Age and at around 2,500 YBP and 3,500 YBP (Burke and Birkeland, 1983; Konrad and Clark, 1998; Clark and Gillespie, 1997; Phillips et al., 2009). Some areas lack evidence of a 3,500 YBP glacial period (Phillips et al., 2009), but sediment cores suggest the formation and growth of glaciers during that time frame (Konrad and Clark, 1998). This discrepancy may result from situational differences including the presence of debris-covered glaciers that have persisted longer than other 
glaciers (Konrad and Clark, 1998). These dates were also established using relative dating methods, radiocarbon dating, and some cosmogenic radionuclide dating.

Most glaciers on the volcanoes of the Cascade Range have prominent sharpcrested moraines that have been dated to a Little Ice Age (LIA) advance (Davis, 1988), and evidence for an advance around 3,000 YBP was documented on a few mountains in the Washington Cascades (Crandall and Miller, 1964; Mahaney et al., 1981). There is also some evidence for an advance around 4,500 - 5,000 YBP (Miller, 1969; Davis, 1988) on Dome Peak, Washington. However, the evidence for pre-Little Ice Age glacial advances is sparse and not synchronous throughout the Cascades. This area is heavily mantled with tephra, particularly ashes from Mount St. Helens, Mount Mazama, and Mount Rainier, that helps to place landforms chronologically when a unique tephras can be found (Davis, 1988). Beget (1981 and 1984) found evidence for an early Holocene advance on Glacier Peak in the Washington Cascades, but it has since been called into question with a reexamination of environmental records and the placement of the carbon used for radiocarbon dating as a possible contribution from a debris flow (Reasoner et al., 2001). These features could be considered late Pleistocene in age.

Other mountain areas in Oregon have not been investigated as thoroughly. Kiver (1974) and Burke (1978) both investigated glacial deposits in the Wallowas in Northeastern Oregon. As with the other ranges there are features dated to the Little Ice Age, as well as a glacial period in the $2,500-3,500$ YBP range. In addition, there is possible evidence of an early Holocene advance (pre-Altithermal) in the 10,000-8,000 
YBP range (Williams, 1974). This is based on the lack of Mount St. Helen's Y tephra in the deposits and thus may represent a late-Pleistocene deposit (Burke and Birkeland, 1983). The dates in this area are imprecise given that no radiocarbon or cosmogenic radionuclide dating has been done. Scott (1977) shows evidence for a Little Ice Age advance and a possible late Pleistocene advance with no other Holocene glacial activity in the Metolius River area, Oregon.

The timing of glacial periods in both the Rocky Mountains and Sierra Nevada is similar. The Neoglaciation in the Cascades differs in that there are only two defined periods of advance. One period is associated with the Little Ice Age and an earlier period with a wide range of dates (Table 1). There is no clear third glacial period throughout the Cascades even though climate proxies for the Cascade Range are consistent with a cold or wet period that would be sufficient for a glacial advances between 2000 YBP to 5500 YBP (Scott, 1977; Lafrenz, 2001; Marcott et al., 2009).

\section{Mount Hood Geological and Glacial History}

The Holocene eruptive history of the central and southern Cascades since 15,000 YBP is better known than for any other volcanic arc. Mount Hood, Oregon formed around 900,000 YBP and is the northernmost and tallest peak in the Oregon Cascades. It has experienced many eruptive periods during the past 15,000 years. One eruptive period occurred during the late Pleistocene $(12,000-15,000$ YBP $)$ and three occurred during the late Holocene $(0-4,000$ YBP); all of these coincide with periods of 
widespread volcanic activity throughout the Cascades (Scott, 1990). However, a dormant phase on Mount Hood occurred while there was an increase in volcanic activity in many other Cascade locations from 5,000 - 10,000 YBP (Scott, 1990). The late Pleistocene Polallie eruptive period occurred in two phases between $34,000-28,000$ YBP and 15,000-12,000 YBP. The last group of Polallie period deposits reflects a decrease in eruptive activity, coinciding with the retreat of the last Pleistocene glaciers (Thouret, 2005).

Around 7,700 YBP Parkdale lavas flowed and about 5 to $10 \mathrm{~cm}$ of Mazama ash was deposited. The Timberline eruptive period (1,500 YBP) was followed by debris flows in the upper Sandy River and later in the Zigzag River. In the late $18^{\text {th }}$ century, the Old Maid eruptive period began (Scott et al., 1997). In the late 1800 s and early 1900 s there were episodic minor explosive eruptions that may have scattered some pumice (Scott et al., 1997). (Table 1) 
Table 1: Timing of Holocene Glacial Advances and Mount Hood's Volcanic Activity

\begin{tabular}{|c|c|c|c|c|c|}
\hline & $\begin{array}{c}\text { Rocky } \\
\text { Mountains } \\
\end{array}$ & $\begin{array}{c}\text { Sierra } \\
\text { Nevada }\end{array}$ & Wallowas & Cascades & $\begin{array}{c}\text { Mount Hood } \\
\text { Eruptive Periods }\end{array}$ \\
\hline & & & & & $\begin{array}{c}12,000-15,000 \text { YBP } \\
\text { Polallie }\end{array}$ \\
\hline & & & & & $\begin{array}{c}\text { 7,700 YBP } \\
\text { Parkdale \& Mazama } \\
\text { Ash }\end{array}$ \\
\hline \multirow[t]{2}{*}{$\begin{array}{l}\text { Earliest } \\
\text { Neoglacial } \\
\text { Glacial Advance }\end{array}$} & $\begin{array}{c}3,500- \\
5,000 \text { YBP }\end{array}$ & $\begin{array}{l}3,500 \\
\text { YBP }\end{array}$ & \multirow{2}{*}{$\begin{array}{l}2,500- \\
3,500 \\
\text { YBP }\end{array}$} & \multirow[t]{2}{*}{$\begin{array}{c}2,000- \\
4,500 \\
\text { YBP }\end{array}$} & \\
\hline & $\begin{array}{c}950- \\
2,500 \text { YBP }\end{array}$ & $\begin{array}{l}2,500 \\
\text { YBP }\end{array}$ & & & $\begin{array}{l}\text { 1,500 YBP } \\
\text { Timberline }\end{array}$ \\
\hline $\begin{array}{l}\text { Recent Glacial } \\
\text { Advance }\end{array}$ & $\begin{array}{c}150-350 \\
\text { YBP }\end{array}$ & $\begin{array}{c}600- \\
700 \text { YBP }\end{array}$ & $\begin{array}{c}150- \\
600 \text { YBP }\end{array}$ & $250 \mathrm{YBP}$ & $\begin{array}{l}200 \text { YBP } \\
\text { Old Maid }\end{array}$ \\
\hline
\end{tabular}

The glacial history on Mount Hood is well documented for the $20^{\text {th }}$ century by historic photographs and recent repeat photography (Lillquist and Walker 2006). Eliot Glacier, located on the northeastern side of Mount Hood, has experienced a pattern of retreat-advance-retreat during the 1900s (Lillquist and Walker, 2006; Jackson, 2007). This is typical for glaciers on Mount Hood and glaciers on other peaks in the Cascade Range. While these glaciers do not respond the same way because of aspect, slope, and other situational conditions, general responses are similar between glaciers in similar situations on different mountains (Jackson, 2007). The similar behavior of glaciers in the Cascades Range allows for general comparisons between the mountains on glacial chronology.

Although a late Neoglacial advance around the $19^{\text {th }}$ century resulted in the formation of prominent sharp-crested moraines, the Holocene history of glaciations on 
Mount Hood prior to the $20^{\text {th }}$ century is poorly documented for a variety of reasons, including volcanic activity, debris flows, forest fires, and late-season snowpack. Lahars frequently bury or obliterate older features, such as terminal moraines, that would aid in dating past glaciations (Crandall, 1980; Scott et al., 1997).

\section{Relative Dating Methods}

Many authors employ relative age-dating techniques to establish chronologies of glacial advances (Nelson, 1954; Sharp, 1969; Birkeland, 1973; Mahaney et al., 1981; Lafrenz, 2001). The Rocky Mountains, Sierra Nevada, and some deposits in the Cascade Range have been studied from this perspective. Methods to distinguish relative ages of glacial deposits include topographic expression and position (Nelson, 1954; Mahaney et al., 1981), soil development (Nelson, 1954; Birkeland, 1973; Scott, 1977; Mahaney et al., 1981; Lafrenz 2001), weathering indicators such as surficial boulder frequency and weathering rinds (Nelson, 1954; Sharp, 1969; Scott, 1977; Mahaney et al., 1981; Lafrenz 2001), lichenometry (Benedict, 1967; Birkeland, 1973; Mahaney et al., 1981), and vegetation cover and community (Mahaney and Spence, 1985).

Terminal moraines are the glacial deposits usually used to determine relative dates because their age relative to other landforms, as a function of distance from the headwall, can be easily established (Benedict, 1973). However, measurements in many comparable sites, such as closely adjacent lateral moraines, can also yield definitive results (Sharp, 1969). 
Relative dating of glacial features in the Cascades is complicated by volcanism. The activity of this range disturbs landforms frequently, masking or obliterating older surfaces. Consequently, the impact of volcanism must be considered in any attempt to establish a chronology in the Cascade Range (Haugland and Burns, 2006).

\section{Soil Development}

Soils are useful for determining the relative ages of hillslopes as the amount of development indicates the history of slope stability or instability over long time spans (Birkeland, 1999; McFadden and Knuepfer, 1990). Typically, the soil profile is described in the field, and samples are taken for further laboratory analyses. The physical characteristics, including color, texture, consistence, structure, particle size, $\mathrm{pH}$, and depth of horizons, are related to soil development and provide a good indicator of relative age.

Table 2: Changes in the Physical Characteristics of Soil with Increased Age

\begin{tabular}{|l|l|l|}
\hline Characteristic & Color & Presence of Clay-sized Particles \\
\hline $\begin{array}{l}\text { Changes with } \\
\text { Increased Age }\end{array}$ & Becomes redder & Increases \\
\hline Explanation & $\begin{array}{l}\text { Soils oxidize over time } \\
\text { developing redder colors }\end{array}$ & $\begin{array}{l}\text { As chemical weathering occurs, the } \\
\text { percentage of clay-sized particles } \\
\text { increases }\end{array}$ \\
\hline $\begin{array}{l}\text { Other characteristics } \\
\text { affected }\end{array}$ & $\mathrm{n} / \mathrm{a}$ & Texture, structure, consistency \\
\hline
\end{tabular}


As the minerals in soils oxidize, the color reddens. Redder colors indicate a more developed soil (Birkeland, 1999). The presence of clay-sized particles is the result of chemical weathering. Normally, the more clays present in a soil the more developed it is (Birkeland, 1999). These particles impact the texture, consistence, and structure of the soil in the field. In the lab, the portion of clay in a sample as shown through a particle size analysis will indicate the amount of development; again, more clays equal more development. Clay content, seen as the "clay bulge" on particle graphs can indicate well- or poorly-developed soils (Mahaney et al., 1981). The depth of a pedon and the thickness of horizons also tend to increase with age (Birkeland, 1999). The $\mathrm{pH}$ of a soil will change with time, but is a less useful for determining relative age; it is however, useful for demonstrating that soils are similar or dissimilar. Examining these characteristics for multiple features can suggest a relative age when compared with each other. This method has seen widespread use on various mountain ranges (Nelson, 1954; Sharp, 1969; Scott, 1977; Alexander, 1986; Birkeland et al., 1991; Allen and Burns, 2000; Lafrenz, 2001; Haugland and Burns, 2006).

Soil development is a function of five general factors, including climate, biota, relief, parent material, and time (Jenny 1941). Site selection on moraines is critical when considering soil development as slope position influences the degree of development. Site selection must be made carefully because elevation exerts a pedogenic influence, and small variations can occur that are not related to time of development (Alexander, 1986). 
The progressive positions for soil development down a slope is referred to as a catena (Milne, 1935). A 5-position catena (Fig 1) begins at the top of the slope (the peak) with the summit position. This is the position of greatest erosion as it is the most exposed. The next position moving down the slope is the shoulder. It is defined as a convex position of the minimal erosion from scour and wasting processes, and it tends to have the greatest soil development. Moving down the slope is the backslope position; a concave portion of the slope that water tends to flow through which can cause erosion and some mass wasting. The bottom two positions are the footslope and toeslope. Both are characterized by contributions from higher positions leading to burial (Milne, 1935).

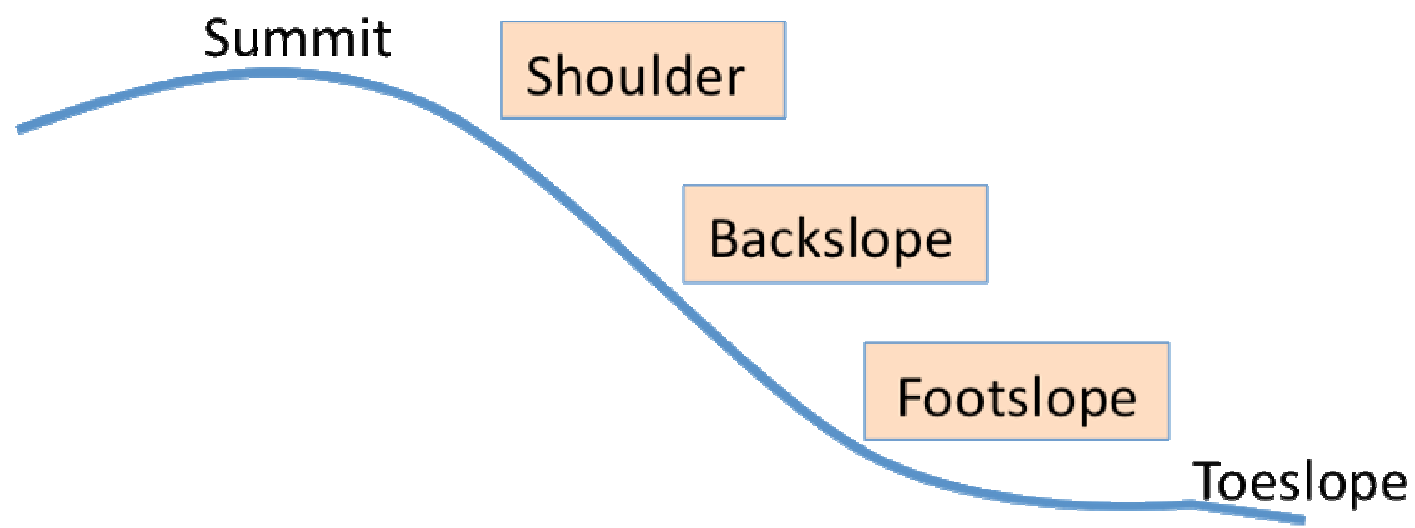

Figure 1: Five Position Catena (Highlighted positions indicate those most favorable for soil analysis on moraines)

A catena is an effective tool for soil development analysis on a moraine because the parent material and time are nearly constant (Birkeland, 1999). The close proximity of the lateral moraines makes them ideal candidates for relative dating using soils. A 
catena study, where all slope positions are sampled, provides more definitive information than a single soil sample from the moraine. By considering all the positions on a slope, a better idea of the overall soil development of the slope can be determined and one can make a more definitive assessment of the difference in relative age among the features. If only one position is considered, this may over- or under-estimate the amount of soil development. However, the literature suggests backslope and footslope positions as the most favorable positions on moraine slopes for soil development because of the unique hydrology found in moraines (Birkeland and Burke, 1988;

Birkeland et al., 1991; Allen and Burns, 2000).

\section{Position}

Topographic position of moraines in relation to one another and topographic expression of landforms suggest relative ages based on cross-cutting relationships, changes in the crest characteristics, and slope (Nelson, 1954; Mahaney et al., 1981). A preliminary examination of Eliot glacier's lateral moraines begins with determining their position relative to other features and each other using maps of geomorphic deposits (Scott et al., 1997), aerial imagery (http://glaciers.research.pdx.edu (last accessed 16 May 2010)), and high-resolution LiDAR-derived DEMs (USGS Seamless Viewer, http://seamless.usgs.gov/website/seamless/viewer.htm (last accessed 31 May 2012)). The aerial imagery and LiDAR data supplement ground mapping and provides a base from which to examine the study area. 


\section{STUDY AREA}

Mount Hood is situated $75 \mathrm{~km}$ east-southeast of Portland, Oregon and $35 \mathrm{~km}$ south of the Columbia River in the High Cascades province. Geologically young (around 900,000 years old), Mount Hood is primarily an andesitic volcano of Pleistocene age. Its volcanic activity is characterized by lava flow and lava dome eruptions (Scott et al., 1997). Mount Hood has also been heavily glaciated, and its flanks are mantled in glacial deposits (Crandall, 1980; Thouret, 2005). There are nine named glaciers that exist on the mountain today (Pirot, 2010). Most of the precipitation occurs between October and April and falls as snow (Lundstrom, 1993; Jackson, 2007). Vegetation on the moraines ranges from mature trees to alpine grasses and shrubs.

Eliot Glacier (Fig 2) sits on the northeast flank of Mount Hood and spans an elevation range from $1920 \mathrm{~m}$ to over $3300 \mathrm{~m}$ near the summit (Lillquist and Walker, 2006). It has exhibited a retreat-advance-retreat pattern since 1901, similar to many other glaciers on Mount Hood. The northeastern flank where Eliot Glacier rests has been relatively unaffected by eruptions since the end of the Pleistocene. Photographs of Eliot Glacier show what appear to be multiple lateral moraines on both sides of the glacier (Fig. 3) and are the subjects of this study. In other studies of this type, terminal moraines are considered for relative dating (Benedict, 1973; Haugland and Burns, 2006). Mount Hood poses an interesting problem in that frequent debris flows, triggered by fall/winter precipitation, have obliterated most of the terminal moraines on the mountain. This is 
the case with Eliot Glacier, with the most recent debris flow occurring in November 2006 (Pirot, 2010). However, the lateral moraines have been left untouched as evidence of glacial position and remain suitable for relative dating.

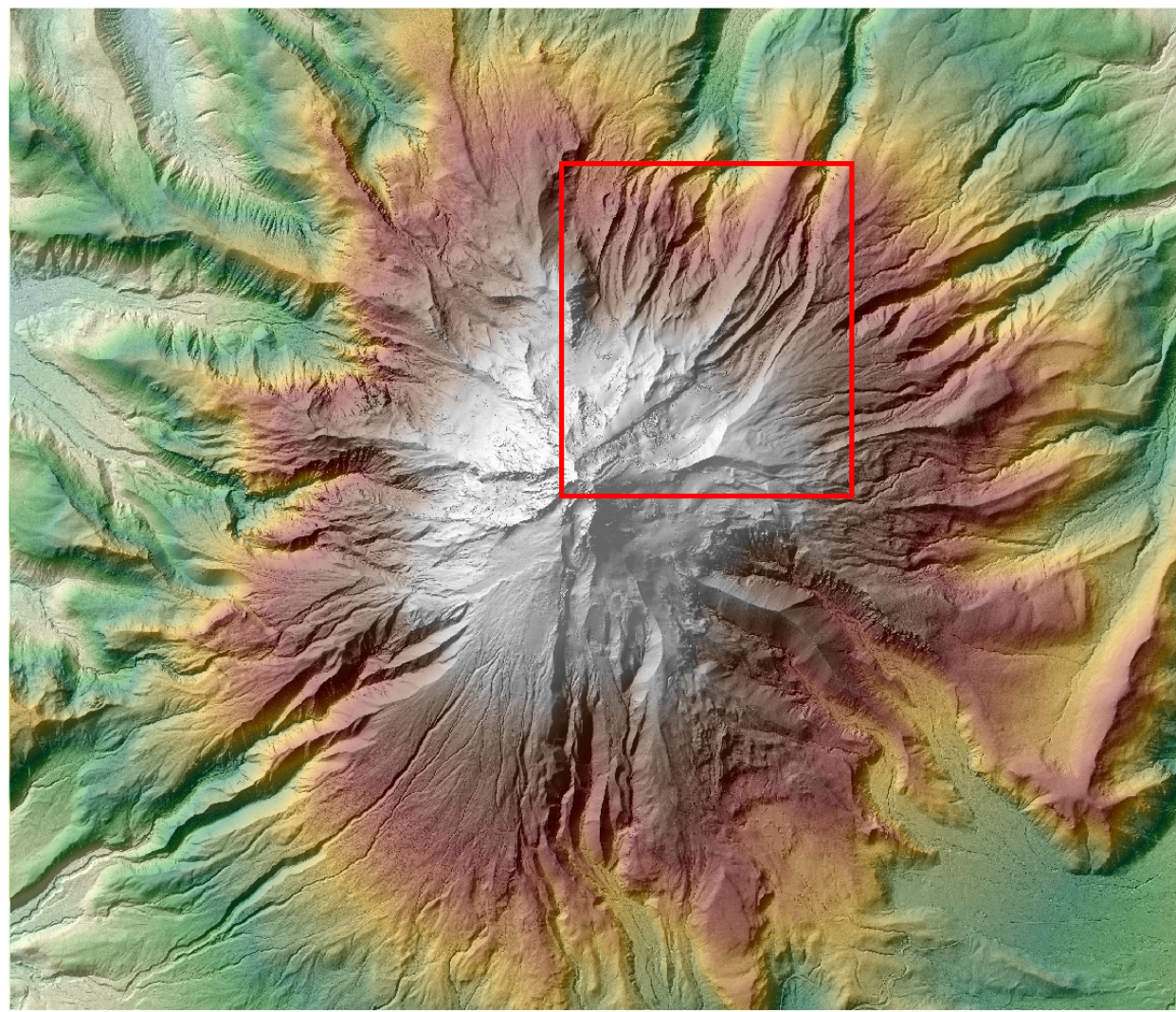

Figure 2: LiDAR imagery of Mount Hood, Eliot Glacier indicated by red box (USGS). 


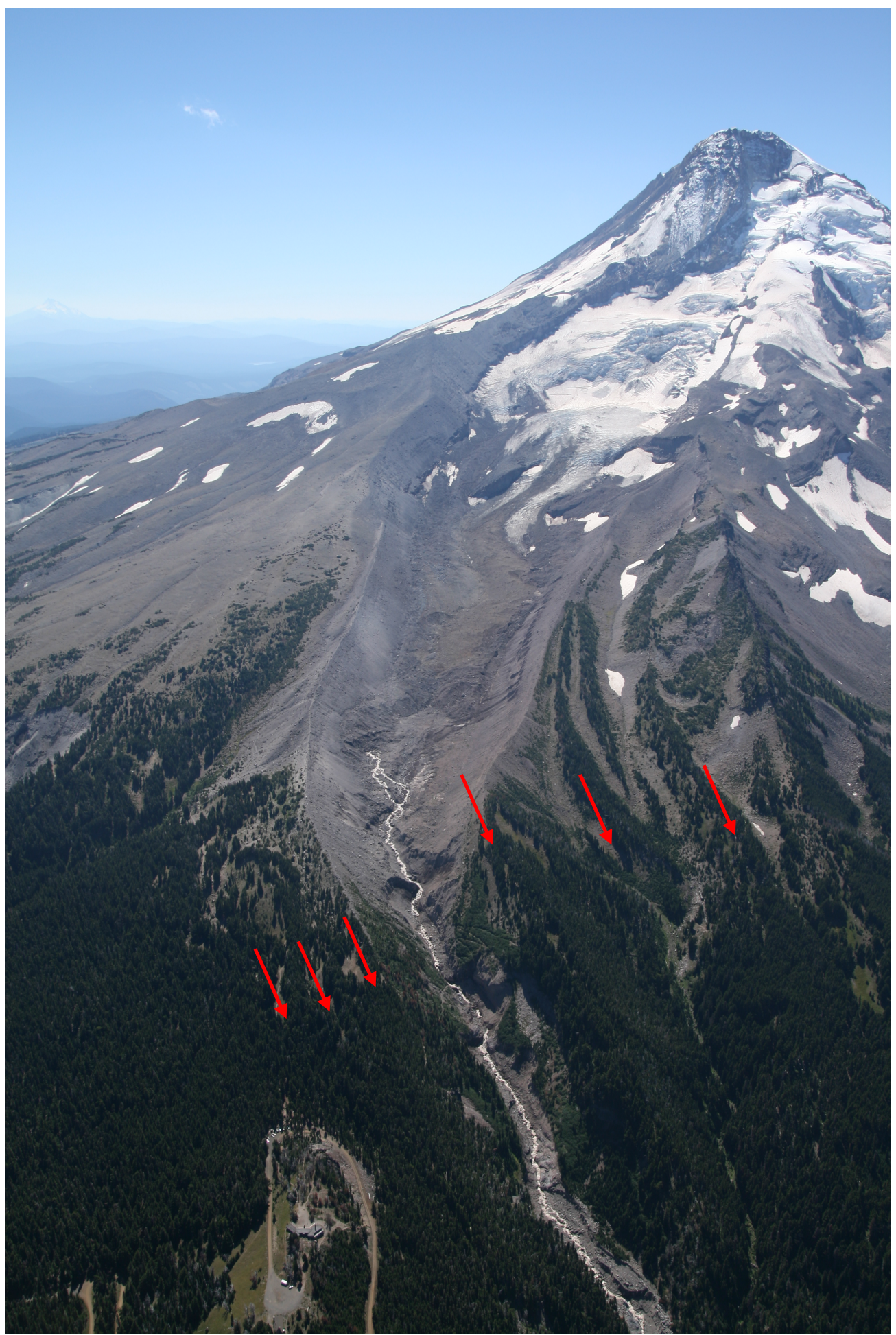

Figure 3: Eliot Glacier, Mount Hood, OR: Lateral moraines indicated by arrows. The three tightly spaced moraines on the left were investigated in this study. (Photographed by John Scurlock, 2007; http://glaciers.research.pdx.edu/ (last accessed 31 May 2012)) 


\section{METHODS}

Aerial imagery and LiDAR were used to narrow the study area and determine the position of the glacial features around Eliot Glacier. Relative dating techniques were then applied to three lateral moraines (Fig. 4) to investigate the Neoglacial history of Eliot Glacier. The selection was based on finding a set of accessible moraines in close proximity to each other. The lateral moraines on the eastern side of the glacier form a set of three features at approximately the same elevation. Thus, the current climate, potential vegetation, parent material, and slope do not differ among these features. These moraines are labeled LIA: closest moraine to the current glacier, M: middle moraine, and O: outer moraine, away from the current glacier.

\section{Field Methods}

In the fall of 2010, soil pits were excavated by hand on the east face (distal side) of each of the three lateral moraines using shovels and crowbars (Fig. 4). The pits were located below the current treeline between $1860 \mathrm{~m}$ and $1890 \mathrm{~m}$ in elevation, which is well below the current active glacier. A Trimble GeoXT GPS receiver was used to establish location. The pits were dug in sequence, at right angles to the contours of the moraine, on each feature (Birkeland et al., 1991). The soils pits were positioned between $1859 \mathrm{~m}$ and $1890 \mathrm{~m}$ in elevation. The pits were located at the shoulder, backslope, and footslope positions and described in the field using the Soil Survey Staff (2006) methods. The same person made moist color determinations, in as similar light 
conditions as practical, using a Munsell color chart. Moist and wet consistence, texture, structure, presence of clay films, and boundary determinations were made using classification guidelines as established by Birkeland (1999). All horizons were sampled, and soil samples were returned to PSU for further analysis.

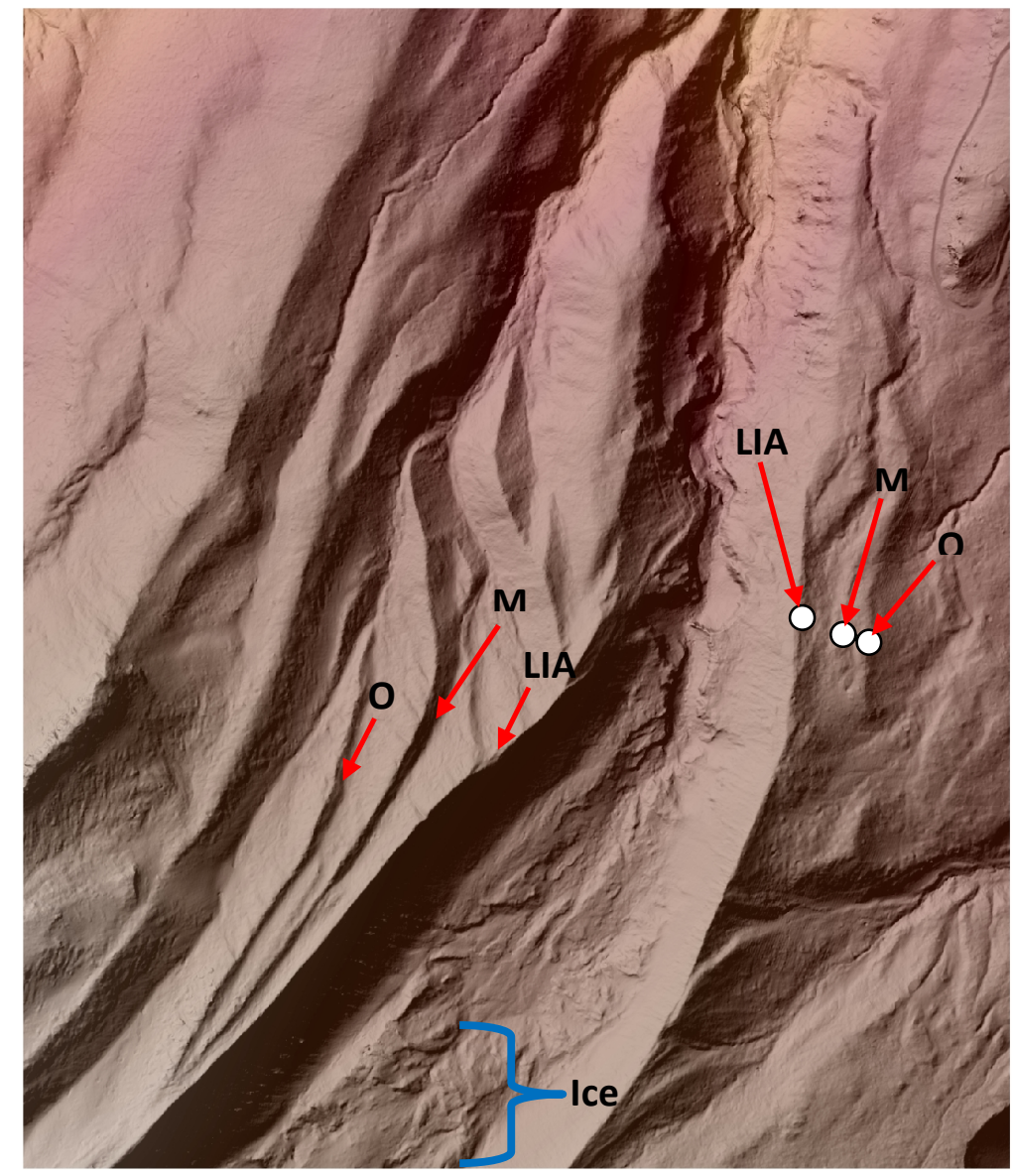

Figure 4: Close up of study area. White dots indicate sampled slopes 


\section{Laboratory Methods}

Laboratory tests of the soil profile samples were used to further determine the

development of each soil. The soil samples from each horizon were analyzed in the PSU Geography Department soil lab for an assessment of $\mathrm{pH}$ and particle size. Field samples were air dried for five days prior to laboratory testing. Each air-dried sample was examined for dry color using a Munsell color chart under similar lighting conditions by the same observer.

The hydrometer method was used to determine the particle size distribution of the different horizons (Gee and Bauder, 1986). Gravels were separated from each sample using a No. 10 sieve. A representative $100 \mathrm{~g}$ sample, obtained using a separator, was used for the particle distribution analysis. The $100 \mathrm{~g}$ of soil was combined with $125 \mathrm{ml}$ of a $5 \mathrm{~g} / \mathrm{L}$ sodium hexametaphosphate solution in a $250 \mathrm{ml}$ beaker to disperse the particles overnight. The sample was re-stirred using a high-speed mechanical mixer for one minute to fully disperse the sample. This slurry was then washed into a $1000 \mathrm{ml}$ graduated cylinder and filled to $1000 \mathrm{ml}$ with distilled water. With a rubber stopper in place, the cylinder was inverted end over end for one minute. The cylinder was then placed in a stable area with approximately constant temperature and measurements were taken at $30 \mathrm{sec}, 1 \mathrm{~min}, 2 \mathrm{~min}, 6 \mathrm{~min}, 20 \mathrm{~min}, 1 \mathrm{hr}, 3 \mathrm{hrs}, 16 \mathrm{hrs}$, and $24 \mathrm{hrs}$ using an ASTM 152H hydrometer. The hydrometer was removed and placed in a graduated cylinder of distilled water in between readings. 
After the hydrometer readings were complete, the contents of the cylinder were wet-sieved through a No. 230 sieve to separate the sand fraction from the silts and clays. The sample was washed on this sieve until the water passing through ran clear. What remained on the sieve was washed into a dish and oven dried overnight. This material was then placed into a stack of sieves (No. 18, 35, 60, 140, and 230) on a shaker in order to separate the different sand size classes. Each size class was weighed separately. Lastly, the particle distribution as a result of the hydrometer analysis was calculated using Stokes' Law (Gee and Bauder, 1986).

Each sample was tested to determine its $\mathrm{pH}(1: 1$ method) and $\mathrm{NaF} \mathrm{pH}$ using the USDA laboratory methods (Burt, 2004; Fields and Perrott, 1966). A positive result from the $\mathrm{NaF} \mathrm{pH}$ test suggests the presence of ash in the sample. For standard $\mathrm{pH}$, a $10 \mathrm{~g}$ portion of air-dried soil was ground fine with a mortar and pestle, mixed with $10 \mathrm{ml}$ of de-ionized water, and stirred thoroughly. After sitting for one hour, the mixture was again stirred for 30 seconds and the $\mathrm{pH}$ was measured using a Thermo Scientific 9156DJWP pH electrode.

For the $\mathrm{NaF} \mathrm{pH,} 1 \mathrm{~g}$ of air-dried sample was ground fine with a mortar and pestle and combined with $50 \mathrm{ml}$ of $1 \mathrm{M} \mathrm{NaF}$ solution with the $\mathrm{pH}$ electrode already inserted. This mixture was stirred for two minutes, and the $\mathrm{pH}$ recorded. To test positive for tephra, the $\mathrm{pH}$ of the sample must rise above 9.4 in less than two minutes (Fields and Perrott, 1966). Two samples from the backslope pit on the $M$ moraine were selected for $\mathrm{NaF} \mathrm{pH}$ testing because their particle size gradation, color, and texture were different 
than the surrounding profile. Both samples tested positive for the presence of ash as a result of a NaF pH test and were sent to Washington State University's (WSU) Microbeam Lab for further testing and identification. Samples from the horizons above and below those that tested positive were also tested, yielding negative results for the $\mathrm{NaF} \mathrm{pH}$ indicating the absence of ash in the samples. Samples from the $\mathrm{O}$ and LIA moraines were tested but also showed negative results. 


\section{RESULTS}

\section{Field Results}

The pits on the $O$ moraine had well-developed $A$ and $A B$ horizons that extended 0 to $57 \mathrm{~cm}$ with Bw horizons present in the backslope and footslope pits (Tables $3-5$ ). The shoulder pit (Fig. 6) on the O moraine had three Cox horizons with varying color development down the profile. The colors ranged from 10YR $4 / 2$ to $10 Y R 5 / 3$. The backslope (Fig. 7) and footslope (Fig.8) pits showed color development with values from $2.5 Y 5 / 3$ to $2.5 Y 6 / 4$ in the Bw horizons. Soil structure was predominantly single grain with non-sticky and non-plastic wet consistence with a loose moist consistence. Vegetation and lichens at each pit location were noted, but not recorded methodically. The O moraine vegetation included coniferous trees, western hemlock (Tsuga heterophylla) and Douglas fir (Pseudotsuga menziesii) with few lichens present on exposed boulders (Fig 5). Lichen species were mainly of the yellow-green variety.

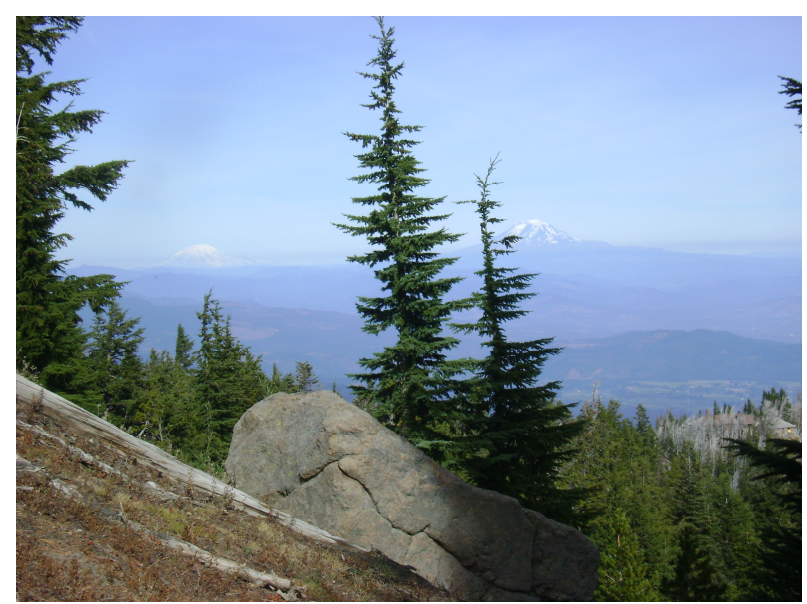

Figure 5: Photo of the distal side of the outer $(\mathrm{O})$ moraine including a glacial erratic. 
Table 3: Field Soil Characteristics of the Shoulder Pit from the O Moraine

\begin{tabular}{|c|c|c|c|c|c|}
\hline Horizon & Depth (cm) & $\begin{array}{l}\text { Moist } \\
\text { Color }\end{array}$ & Structure & Consistence & Boundary \\
\hline$A$ & $0-25$ & $\begin{array}{c}10 Y R \\
4 / 2\end{array}$ & sg & $\begin{array}{c}\text { Wet: so/po } \\
\text { Moist: lo }\end{array}$ & $g, s$ \\
\hline$A B$ & $25-44$ & $\begin{array}{c}10 Y R \\
5 / 2\end{array}$ & sg & $\begin{array}{c}\text { Wet: so/po } \\
\text { Moist: lo }\end{array}$ & C, $\mathrm{s}$ \\
\hline $2 \operatorname{Cox}$ & $44-58$ & $\begin{array}{c}10 Y R \\
5 / 3\end{array}$ & $\mathrm{sg}$ & $\begin{array}{l}\text { Wet: ss/po } \\
\text { Moist: vfr }\end{array}$ & C, $s$ \\
\hline $3 \operatorname{Cox} 1$ & $58-82$ & $\begin{array}{c}10 Y R \\
5 / 3\end{array}$ & sg & $\begin{array}{c}\text { Wet: so/po } \\
\text { Moist: lo }\end{array}$ & C, $\mathrm{s}$ \\
\hline $3 \operatorname{Cox} 2$ & $82-109+$ & $\begin{array}{c}10 Y R \\
5 / 3\end{array}$ & sg & $\begin{array}{c}\text { Wet: so/po } \\
\text { Moist: lo }\end{array}$ & \\
\hline
\end{tabular}

Table 4: Soil Characteristics of the Backslope Pit from the O Moraine

\begin{tabular}{|l|c|c|c|c|c|}
\hline Horizon & Depth (cm) & $\begin{array}{c}\text { Moist } \\
\text { Color }\end{array}$ & Structure & Consistence & Boundary \\
\hline A & $0-11$ & $\begin{array}{c}10 Y R \\
4 / 2\end{array}$ & sg & $\begin{array}{c}\text { Wet: so/po } \\
\text { Moist: lo }\end{array}$ & g, s \\
\hline AB1 & $11-33$ & $\begin{array}{c}10 Y R \\
5 / 3\end{array}$ & sg & $\begin{array}{c}\text { Wet: so/po } \\
\text { Moist: lo }\end{array}$ & g, s \\
\hline AB2 & $33-57$ & $2.5 Y 5 / 3$ & sg & $\begin{array}{c}\text { Wet: so/po } \\
\text { Moist: lo }\end{array}$ & c, w \\
\hline Bw & $57-93+$ & $2.5 Y 6 / 4$ & sg & $\begin{array}{c}\text { Wet: so/po } \\
\text { Moist: lo }\end{array}$ & \\
\hline
\end{tabular}

Table 5: Soil Characteristics of the Footslope Pit from the O Moraine

\begin{tabular}{|l|c|c|c|c|c|}
\hline Horizon & Depth $(\mathrm{cm})$ & $\begin{array}{c}\text { Moist } \\
\text { Color }\end{array}$ & Structure & Consistence & Boundary \\
\hline $\mathrm{A}$ & $0-6$ & $\begin{array}{c}10 \mathrm{YR} \\
5 / 2\end{array}$ & $\mathrm{sg}$ & $\begin{array}{c}\text { Wet: so/po } \\
\text { Moist: lo }\end{array}$ & $\mathrm{g}, \mathrm{s}$ \\
\hline $\mathrm{AB1}$ & $6-30$ & $\begin{array}{c}10 \mathrm{YR} \\
4 / 2\end{array}$ & $\mathrm{sg}$ & $\begin{array}{c}\text { Wet: so/po } \\
\text { Moist: lo }\end{array}$ & $\mathrm{g}, \mathrm{s}$ \\
\hline $\mathrm{AB2}$ & $30-48$ & $\begin{array}{c}10 \mathrm{YR} \\
5 / 3\end{array}$ & $\mathrm{sg}$ & $\begin{array}{c}\text { Wet: so/po } \\
\text { Moist: lo }\end{array}$ & $\mathrm{c}, \mathrm{s}$ \\
\hline $\mathrm{Bw}$ & $48-95+$ & $2.5 \mathrm{Y} 6 / 4$ & $1, \mathrm{f}, \mathrm{sbk}$ & $\begin{array}{c}\text { Wet: so/po } \\
\text { Moist: lo }\end{array}$ & \\
\hline
\end{tabular}




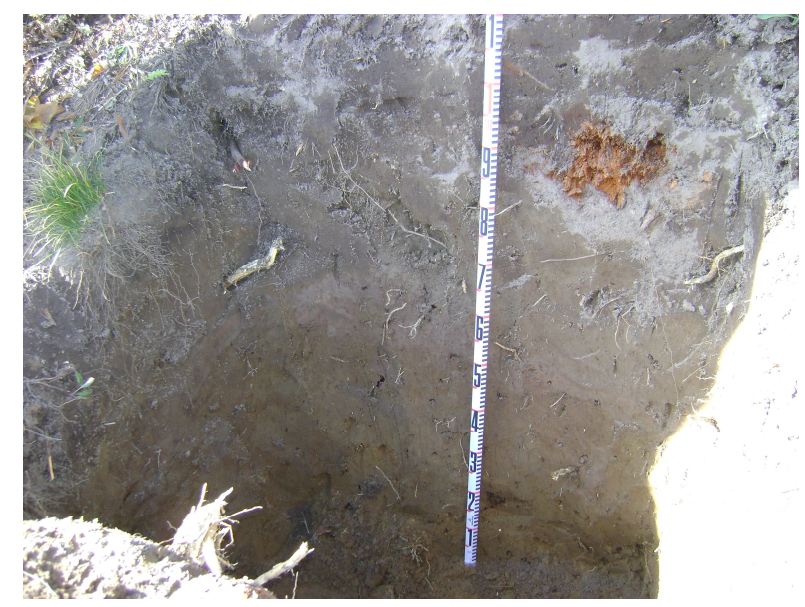

Figure 6: Photo of shoulder pit on the 0 moraine.

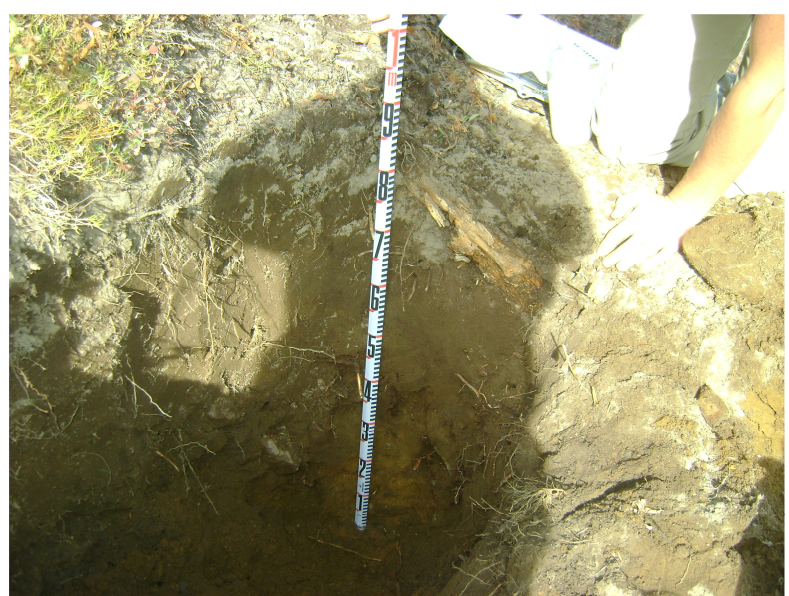

Figure 7: Photo of backslope pit on the O moraine.

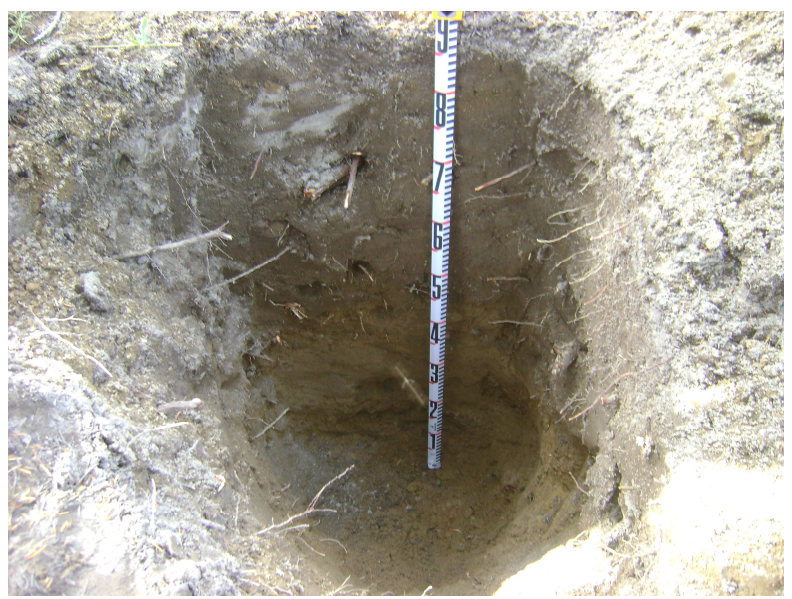

Figure 8: Photo of footslope pit on the O moraine. 
The pits on the $\mathrm{M}$ moraine showed less color development than the $\mathrm{O}$ moraine. The $A$ and $A B$ horizons were shallow (0 to $36 \mathrm{~cm}$ ) in the backslope (Fig. 10) and footslope (Fig. 11) pits, extending to $55 \mathrm{~cm}$ in the shoulder position (Fig. 9; Tables $6-8$ ). The structure of the horizons varied from single grain to small subangular blocky. The colors range from 10YR $3 / 2$ to $10 Y R 6 / 2$, with the Bw horizons showing $2.5 Y 5 / 3$ and $5 / 2$. In the backslope pit (Fig. 8), the two Cox horizons were unusual. Field hues were gray (2Coxb) and pink (3Coxb). The pink horizon exhibited a platy, very friable structure. These two horizons had abrupt boundaries incongruous with the rest of the profile. No other horizons in any of the pits looked like these horizons. The $\mathrm{M}$ moraine also had western hemlock (Tsuga heterophylla) and Douglas fir (Pseudotsuga menziesii), and a few lichens. Vegetation was abundant grass cover and some shrubs. 


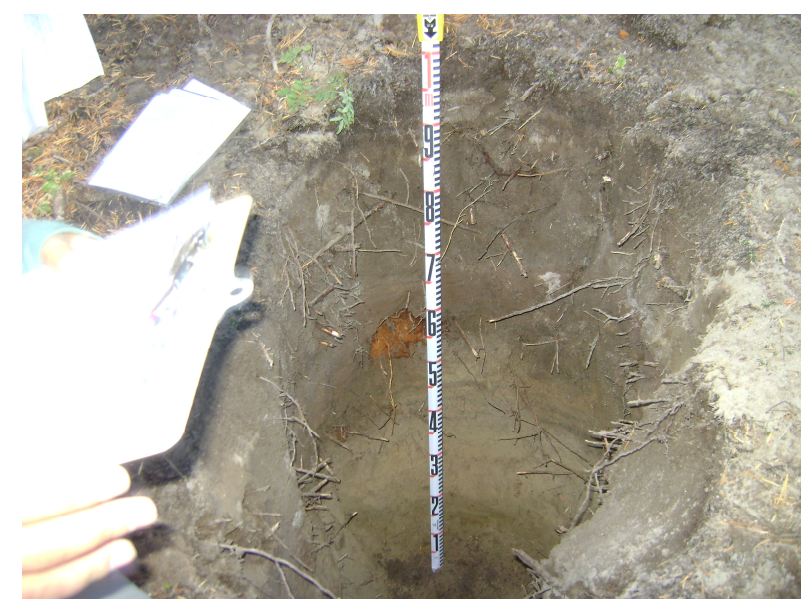

Figure 9: Photo of shoulder pit on the $\mathrm{M}$ moraine.

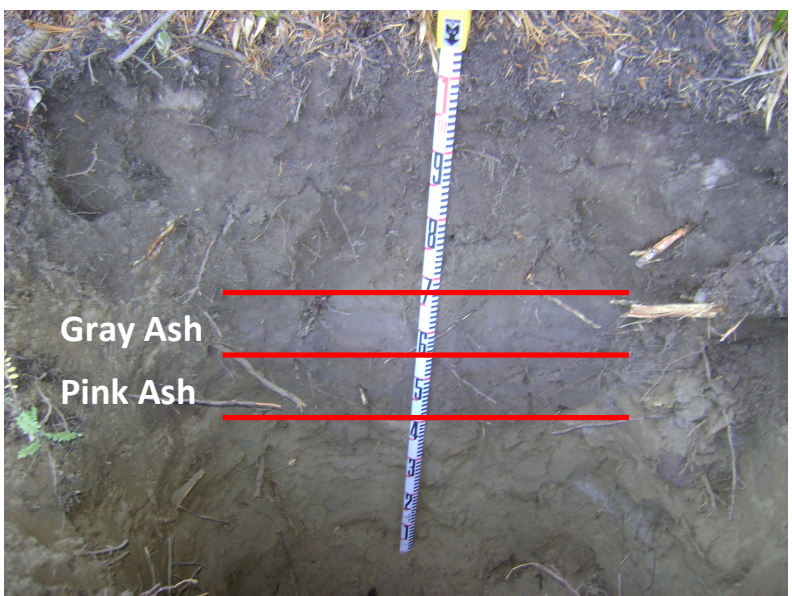

Figure 10: Photo of backslope pit on the M moraine.

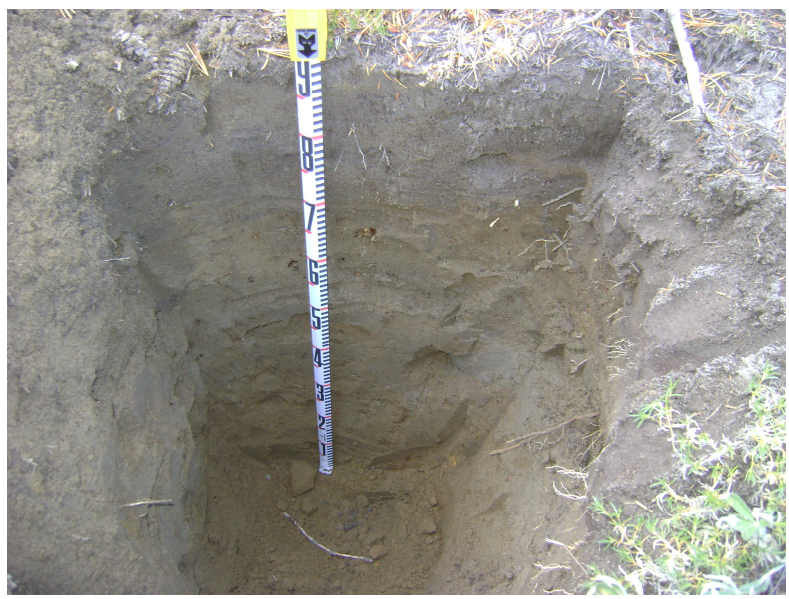

Figure 11: Photo of footslope pit on the M moraine. 
Table 6: Soil Characteristics of the Shoulder Pit from the M Moraine

\begin{tabular}{|l|c|c|c|c|c|}
\hline Horizon & Depth (cm) & $\begin{array}{c}\text { Moist } \\
\text { Color }\end{array}$ & Structure & Consistence & Boundary \\
\hline A & $0-5$ & $\begin{array}{c}10 Y R \\
3 / 2\end{array}$ & sg & $\begin{array}{c}\text { Wet: so/po } \\
\text { Moist: lo }\end{array}$ & c, s \\
\hline AB & $5-55$ & $\begin{array}{c}10 Y R \\
5 / 2\end{array}$ & $1, f$, sbk & $\begin{array}{c}\text { Wet: so/po } \\
\text { Moist: vfr }\end{array}$ & c, s \\
\hline Bw & $55-100+$ & $\begin{array}{c}10 Y R \\
5 / 3\end{array}$ & $1, f$, sbk & $\begin{array}{c}\text { Wet: so/po } \\
\text { Moist: vfr }\end{array}$ & \\
\hline
\end{tabular}

Table 7: Field Soil Characteristics of the Backslope Pit from the M Moraine

\begin{tabular}{|l|c|c|c|c|c|}
\hline Horizon & Depth (cm) & $\begin{array}{c}\text { Moist } \\
\text { Color }\end{array}$ & Structure & Consistence & Boundary \\
\hline $\mathrm{A}$ & $0-5$ & $\begin{array}{c}10 Y \mathrm{Y} \\
4 / 2\end{array}$ & $\mathrm{sg}$ & $\begin{array}{c}\text { Wet: so/po } \\
\text { Moist: lo }\end{array}$ & $\mathrm{g}, \mathrm{s}$ \\
\hline $\mathrm{AB}$ & $5-36$ & $\begin{array}{c}10 Y \mathrm{Y} \\
5 / 2\end{array}$ & $\mathrm{sg}$ & $\begin{array}{c}\text { Wet: so/po } \\
\text { Moist: lo }\end{array}$ & $\mathrm{a}, \mathrm{s}$ \\
\hline 2Coxb & $36-40$ & $\begin{array}{c}10 Y \mathrm{Y} \\
6 / 2\end{array}$ & $1, \mathrm{f}, \mathrm{sbk}$ & $\begin{array}{c}\text { Wet: so/po } \\
\text { Moist: vfr }\end{array}$ & $\mathrm{a}, \mathrm{s}$ \\
\hline 3Coxb & $40-51$ & $\begin{array}{c}10 Y \mathrm{Y} \\
6 / 2\end{array}$ & $2, \mathrm{~m}, \mathrm{pl}$ & $\begin{array}{c}\text { Wet: ss/po } \\
\text { Moist: vfr }\end{array}$ & $\mathrm{a}, \mathrm{s}$ \\
\hline 3Bwb & $51-100+$ & $\begin{array}{c}2.5 \mathrm{Y} \\
5 / 3\end{array}$ & $1, \mathrm{f}, \mathrm{sbk}$ & $\begin{array}{c}\text { Wet: so/po } \\
\text { Moist: vfr }\end{array}$ & \\
\hline
\end{tabular}

Table 8: Soil Characteristics of the Footslope Pit from the M Moraine

\begin{tabular}{|l|c|c|c|c|c|}
\hline Horizon & Depth $(\mathrm{cm})$ & $\begin{array}{c}\text { Moist } \\
\text { Color }\end{array}$ & Structure & Consistence & Boundary \\
\hline A & $0-21$ & $\begin{array}{c}10 Y R \\
3 / 2\end{array}$ & $1, f, s b k$ & $\begin{array}{c}\text { Wet: so/po } \\
\text { Moist: vfr }\end{array}$ & c, s \\
\hline Bw1 & $21-40$ & $\begin{array}{c}2.5 Y \\
5 / 3\end{array}$ & $2, \mathrm{~m}, \mathrm{sbk}$ & $\begin{array}{c}\text { Wet: so/po } \\
\text { Moist: vfr }\end{array}$ & c, s \\
\hline Bw2 & $40-90+$ & $\begin{array}{c}2.5 \mathrm{Y} \\
5 / 2\end{array}$ & $1, \mathrm{f}, \mathrm{sbk}$ & $\begin{array}{c}\text { Wet: so/po } \\
\text { Moist: vfr }\end{array}$ & \\
\hline
\end{tabular}


The LIA moraine exhibited little soil development. All the pits (Figs. $13-15$ ) have poorly established A over $\mathrm{C}$ horizons that extended to the bottom of the pit (Tables $9-$ 11). The A horizon was identified by the presence of some organic material mixed with the mineral components near the surface. The boundary determinations were made by hand texturing every few centimeters down the profile to determine where a change occurred. Moisture also played a role in boundary determinations. The colors showed little differentiation, ranging from $10 Y R 5 / 1$ to $5 / 2$. The structure was entirely single grain. Consistence varied slightly with the presence of organics. The LIA moraine had little vegetation that included a few whitebark pine (Pinus albicaulis) and scattered small scrub plants (Fig 12). There was no consistent ground cover. The lichens on the LIA moraine varied in color and size, indicating many species were present.

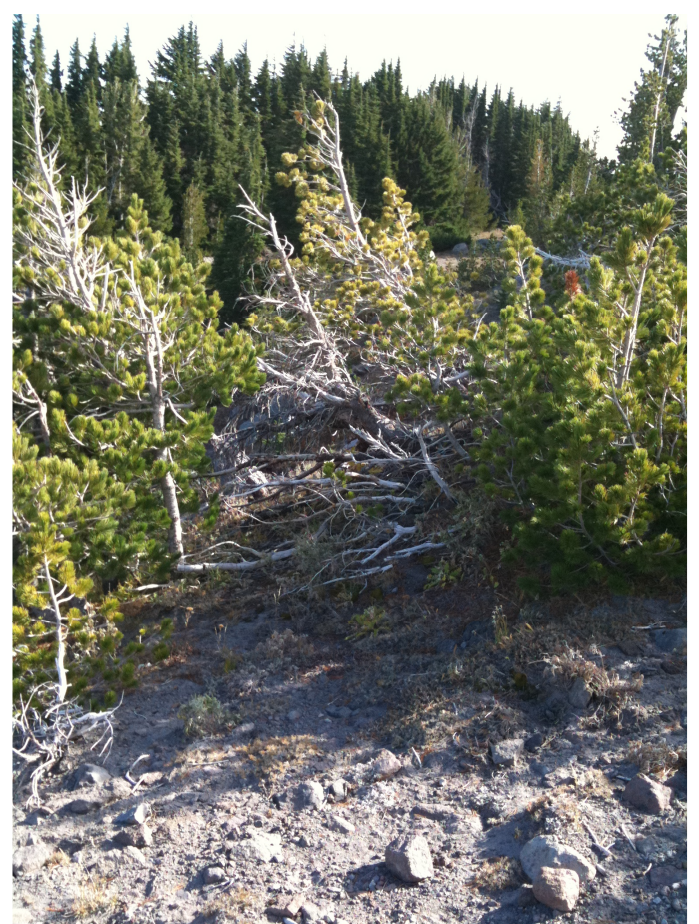

Figure 12: Photo of vegetation on LIA moraine. Trees on the $\mathrm{M}$ moraine can be seen in the background. 


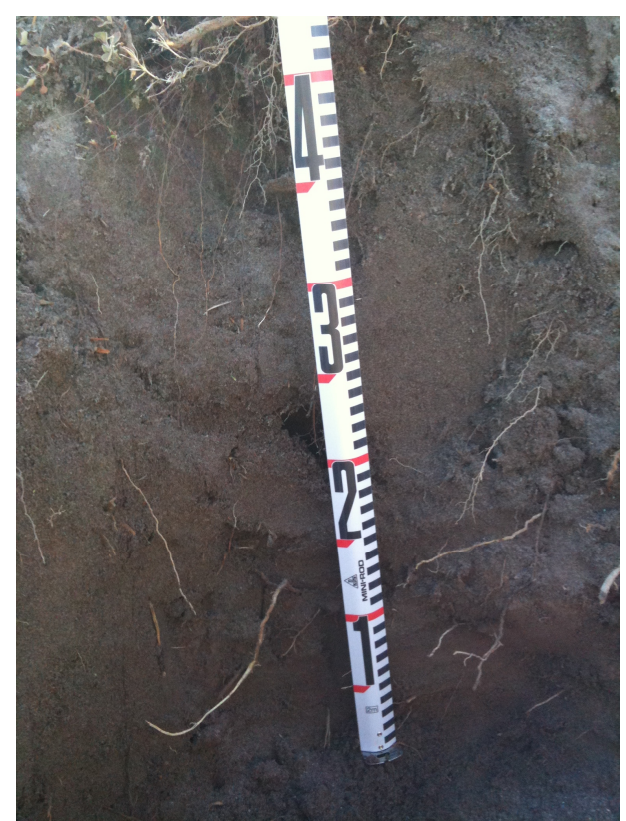

Figure 13: Photo of shoulder pit on the LIA moraine.

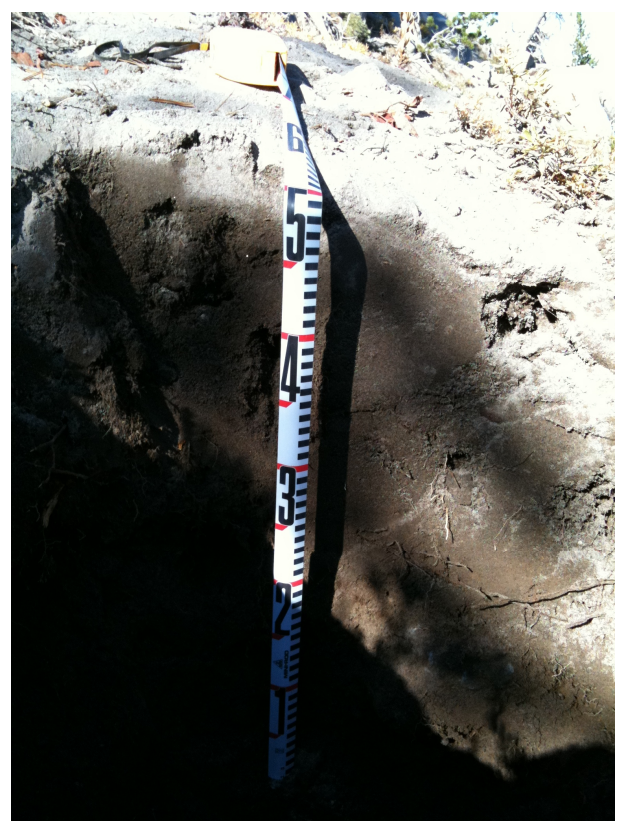

Figure 14: Photo of backslope pit on the LIA moraine.

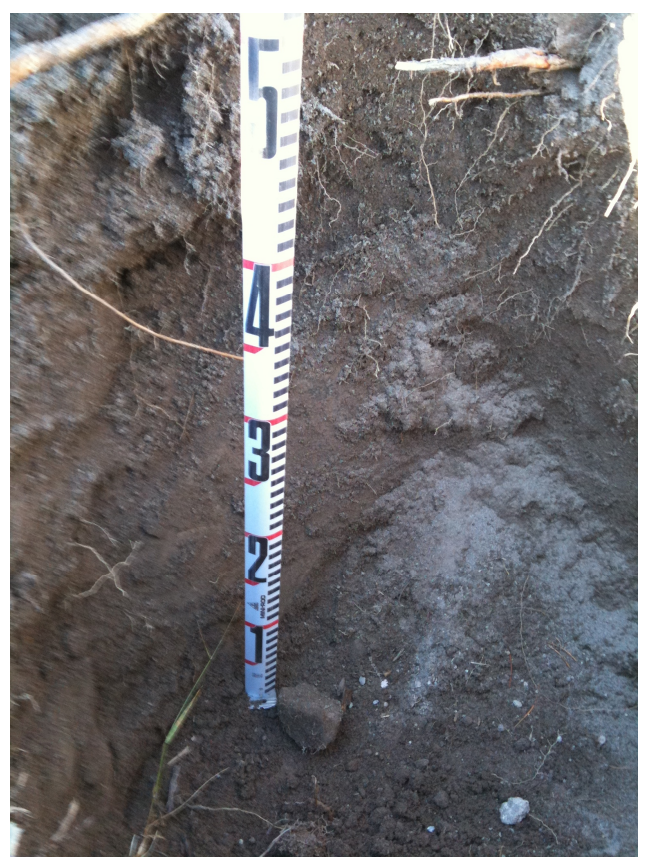

Figure 15: Photo of footslope pit on LIA moraine 
Table 9: Soil Characteristics of the Shoulder Pit from the LIA Moraine

\begin{tabular}{|l|c|c|c|c|c|}
\hline Horizon & Depth $(\mathrm{cm})$ & $\begin{array}{c}\text { Moist } \\
\text { Color }\end{array}$ & Structure & Consistence & Boundary \\
\hline A & $0-10$ & $\begin{array}{c}10 Y R \\
5 / 1\end{array}$ & sg & $\begin{array}{c}\text { Wet: ss/ps } \\
\text { Moist: lo }\end{array}$ & $\mathrm{g}$ \\
\hline C & $10-50+$ & $\begin{array}{c}10 Y R \\
5 / 1\end{array}$ & sg & $\begin{array}{c}\text { Wet: ss/po } \\
\text { Moist: lo }\end{array}$ & \\
\hline
\end{tabular}

Table 10: Soil Characteristics of the Backslope Pit from the LIA Moraine

\begin{tabular}{|l|c|c|c|c|c|}
\hline Horizon & Depth $(\mathrm{cm})$ & $\begin{array}{c}\text { Moist } \\
\text { Color }\end{array}$ & Structure & Consistence & Boundary \\
\hline A & $0-3$ & $\begin{array}{c}10 Y R \\
5 / 2\end{array}$ & sg & $\begin{array}{c}\text { Wet: ss/po } \\
\text { Moist: lo }\end{array}$ & $\mathrm{g}$ \\
\hline C & $3-50+$ & $\begin{array}{c}10 Y R \\
5 / 1\end{array}$ & sg & $\begin{array}{c}\text { Wet: so/po } \\
\text { Moist: lo }\end{array}$ & \\
\hline
\end{tabular}

Table 11: Soil Characteristics of the Footslope Pit from the LIA Moraine

\begin{tabular}{|l|c|c|c|c|c|}
\hline Horizon & Depth $(\mathrm{cm})$ & $\begin{array}{c}\text { Moist } \\
\text { Color }\end{array}$ & Structure & Consistence & Boundary \\
\hline A & $0-8$ & $\begin{array}{c}10 Y R \\
5 / 2\end{array}$ & sg & $\begin{array}{c}\text { Wet: ss/po } \\
\text { Moist: lo }\end{array}$ & $\mathrm{g}$ \\
\hline C & $8-50+$ & $\begin{array}{c}10 Y R \\
5 / 2\end{array}$ & sg & $\begin{array}{c}\text { Wet: so/po } \\
\text { Moist: lo }\end{array}$ & \\
\hline
\end{tabular}




\section{Laboratory Results}

Laboratory analyses included the determination of particle size and $\mathrm{pH}$. These analyses were used to complete the process of soil classification and to assess the soil's andic properties. Particle size analysis on the $\mathrm{O}$ moraine pits identified sand as the dominant size class with fine sand the major component (Tables 12 -17). A "silt bulge"

(Figs $16-18$ ) in the $\mathrm{O}$ moraine pits is evident. There is little clay in any of the pits on any feature. The textures in all the $\mathrm{O}$ horizons were loamy sand to sand. The $\mathrm{pH}$ in the pits varied from 5.2 to 5.6. The silt-rich horizon in the shoulder pit (2Cox) tested negative for ash content using the $\mathrm{NaF} \mathrm{pH}$ test. None of the other horizons in any of the $\mathrm{O}$ moraine pits exhibited characteristics of ash content.

Using the Keys to Soils Taxonomy (2006), these soils are classified as Andic Haplocryepts. Andic indicates that volcanic products make up a portion of the soil. Haplo- classifies the soil as "other", meaning the soil does not meet any criteria for another specific type. The -cry- segment ("cryic") indicates the cold temperature of the formative environment (mean annual temperature $<8^{\circ} \mathrm{C}$ at $50 \mathrm{~cm}$ ). Lastly the -ept portion refers to the primary classification as an Inceptisol, a relatively poorly developed soil with a Bw horizon. 
Table 12: Lab Soil Characteristics of the Shoulder Pit from the O Moraine

\begin{tabular}{|l|c|c|c|c|c|c|c|}
\hline Horizon & $\begin{array}{c}\text { Depth } \\
(\mathrm{cm})\end{array}$ & $\begin{array}{c}\mathrm{pH} \\
(1: 1)\end{array}$ & Texture & $\begin{array}{c}\text { Gravel } \\
(\%)\end{array}$ & Sand (\%) & Silt (\%) & Clay (\%) \\
\hline $\mathrm{A}$ & $0-25$ & 5.5 & Loamy Sand & 15 & 85 & 12 & 3 \\
\hline $\mathrm{AB}$ & $25-44$ & 5.4 & Loamy Sand & 7 & 83 & 14 & 3 \\
\hline 2 Cox & $44-58$ & 5.5 & Sandy Loam & 0 & 56 & 40 & 4 \\
\hline 3 Cox1 & $58-82$ & 5.5 & Loamy Sand & 10 & 84 & 13 & 3 \\
\hline 3 Cox2 & $82-109+$ & 5.6 & Loamy Sand & 9 & 81 & 15 & 4 \\
\hline
\end{tabular}

Table 13: Sand Particle Size Distribution of the Shoulder Pit from the O Moraine

\begin{tabular}{|l|c|c|c|c|c|c|}
\hline Horizon & Depth (cm) & $\begin{array}{c}\text { Very Coarse } \\
(\%)\end{array}$ & $\begin{array}{c}\text { Coarse } \\
(\%)\end{array}$ & $\begin{array}{c}\text { Medium } \\
(\%)\end{array}$ & Fine (\%) & $\begin{array}{c}\text { Very Fine } \\
(\%)\end{array}$ \\
\hline A & $0-25$ & 3 & 7 & 17 & 39 & 16 \\
\hline AB & $25-44$ & 2 & 6 & 15 & 42 & 14 \\
\hline 2 Cox & $44-58$ & 1 & 1 & 4 & 22 & 19 \\
\hline 3 Cox1 & $58-82$ & 3 & 5 & 13 & 36 & 22 \\
\hline 3 Cox2 & $82-109+$ & 3 & 6 & 12 & 36 & 22 \\
\hline
\end{tabular}

\section{Particle Size Distribution (\%)}

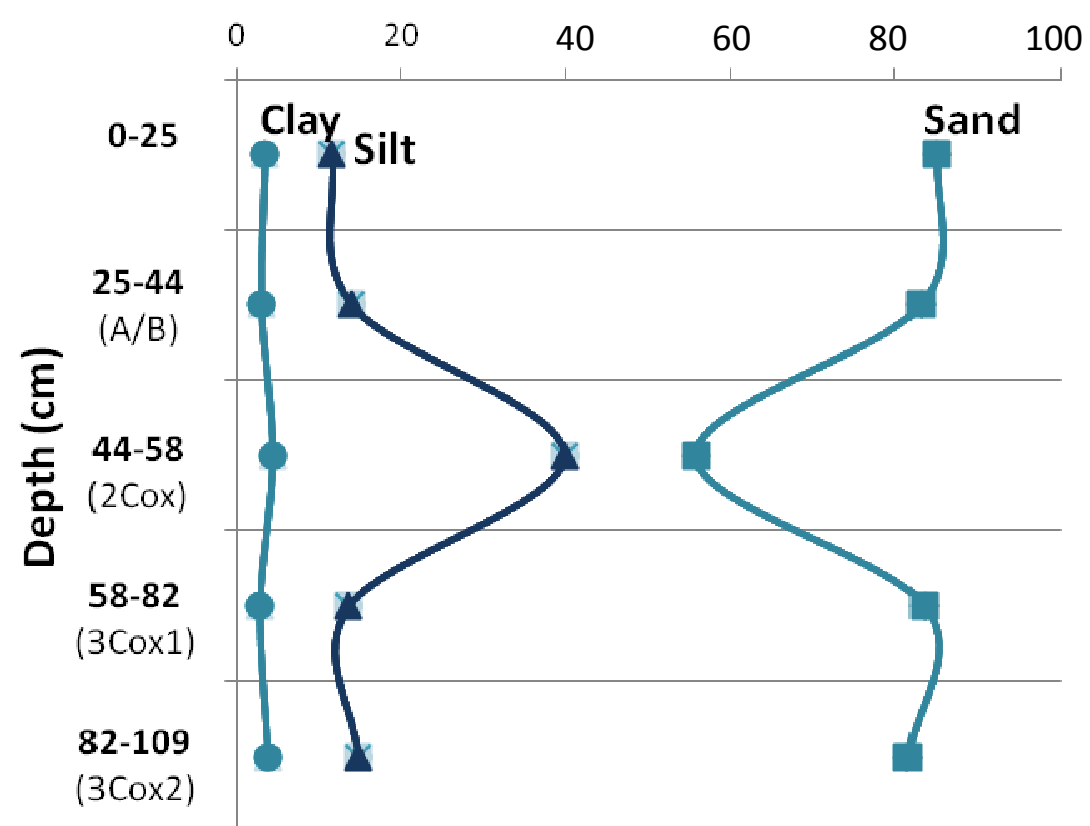

Figure 16: Particle Size Distribution of the Shoulder Pit from the O Moraine 
Table 14: Lab Soil Characteristics of the Backslope Pit from the O Moraine

\begin{tabular}{|l|c|c|c|c|c|c|c|}
\hline Horizon & $\begin{array}{c}\text { Depth } \\
(\mathrm{cm})\end{array}$ & $\begin{array}{c}\mathrm{pH} \\
(1: 1)\end{array}$ & Texture & $\begin{array}{c}\text { Gravel } \\
(\%)\end{array}$ & Sand (\%) & Silt (\%) & Clay (\%) \\
\hline $\mathrm{A}$ & $0-11$ & 5.2 & Loamy Sand & 3 & 84 & 13 & 3 \\
\hline $\mathrm{AB} 1$ & $11-33$ & 5.2 & Loamy Sand & 2 & 85 & 12 & 3 \\
\hline $\mathrm{AB} 2$ & $33-57$ & 5.4 & Sand & 4 & 88 & 8 & 4 \\
\hline $\mathrm{Bw}$ & $57-93+$ & 5.5 & Loamy Sand & 18 & 83 & 14 & 3 \\
\hline
\end{tabular}

Table 15: Sand Particle Size Distribution of the Backslope Pit from the O Moraine

\begin{tabular}{|l|c|c|c|c|c|c|}
\hline Horizon & Depth (cm) & $\begin{array}{c}\text { Very Coarse } \\
(\%)\end{array}$ & $\begin{array}{c}\text { Coarse } \\
(\%)\end{array}$ & $\begin{array}{c}\text { Medium } \\
(\%)\end{array}$ & Fine (\%) & $\begin{array}{c}\text { Very Fine } \\
(\%)\end{array}$ \\
\hline$A$ & $0-11$ & 2 & 4 & 13 & 42 & 19 \\
\hline$A B 1$ & $11-33$ & 2 & 4 & 12 & 44 & 17 \\
\hline$A B 2$ & $33-57$ & 2 & 5 & 14 & 44 & 17 \\
\hline$B w$ & $57-93+$ & 5 & 7 & 14 & 37 & 18 \\
\hline
\end{tabular}

\section{Particle Size Distribution (\%)}

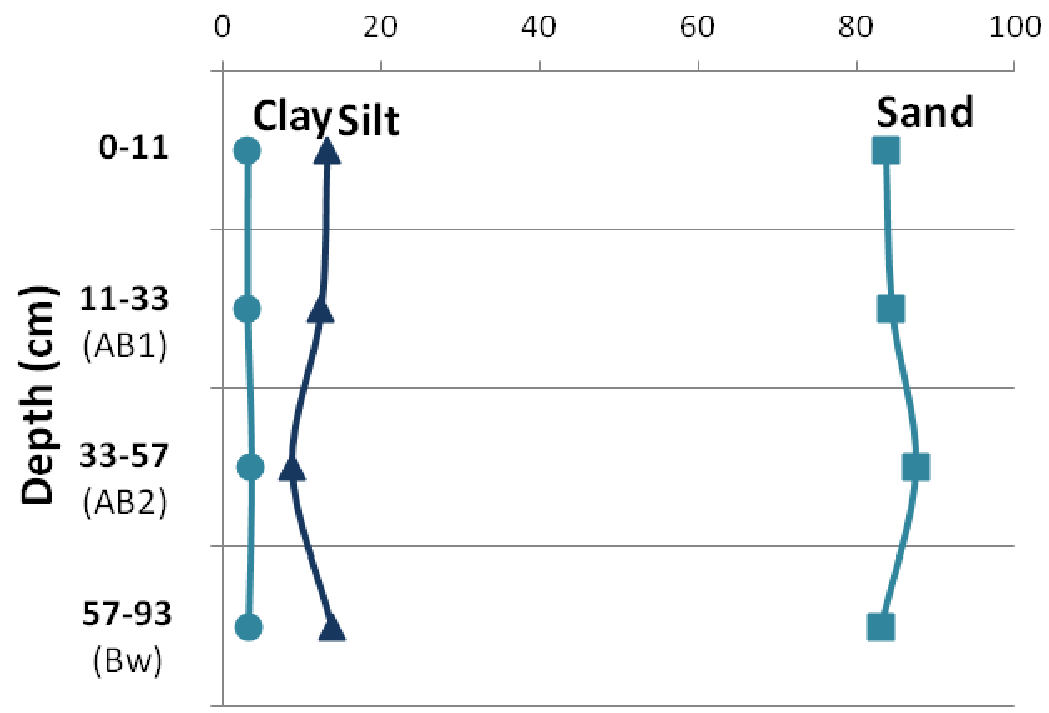

Figure 17: Particle Size Distribution of the Backslope Pit from the O Moraine 
Table 16: Lab Soil Characteristics of the Footslope Pit from the O Moraine

\begin{tabular}{|l|c|c|c|c|c|c|c|}
\hline Horizon & $\begin{array}{c}\text { Depth } \\
(\mathrm{cm})\end{array}$ & $\begin{array}{c}\mathrm{pH} \\
(1: 1)\end{array}$ & Texture & $\begin{array}{c}\text { Gravel } \\
(\%)\end{array}$ & Sand (\%) & Silt (\%) & Clay (\%) \\
\hline A & $0-6$ & 5.2 & Sand & 4 & 88 & 9 & 3 \\
\hline AB1 & $6-30$ & 5.2 & Sand & 4 & 88 & 9 & 3 \\
\hline AB2 & $30-48$ & 5.3 & Loamy Sand & 8 & 85 & 11 & 4 \\
\hline Bw & $48-95+$ & 5.4 & Loamy Sand & 19 & 85 & 12 & 3 \\
\hline
\end{tabular}

Table 17: Sand Particle Size Distribution of the Footslope Pit from the O Moraine

\begin{tabular}{|l|c|c|c|c|c|c|}
\hline Horizon & Depth $(\mathrm{cm})$ & $\begin{array}{c}\text { Very Coarse } \\
(\%)\end{array}$ & $\begin{array}{c}\text { Coarse } \\
(\%)\end{array}$ & $\begin{array}{c}\text { Medium } \\
(\%)\end{array}$ & Fine (\%) & $\begin{array}{c}\text { Very Fine } \\
(\%)\end{array}$ \\
\hline A & $0-6$ & 2 & 7 & 20 & 39 & 17 \\
\hline AB1 & $6-30$ & 3 & 7 & 20 & 42 & 14 \\
\hline AB2 & $30-48$ & 3 & 7 & 18 & 39 & 15 \\
\hline Bw & $48-95+$ & 4 & 7 & 16 & 38 & 17 \\
\hline
\end{tabular}

Particle Size Distribution (\%)

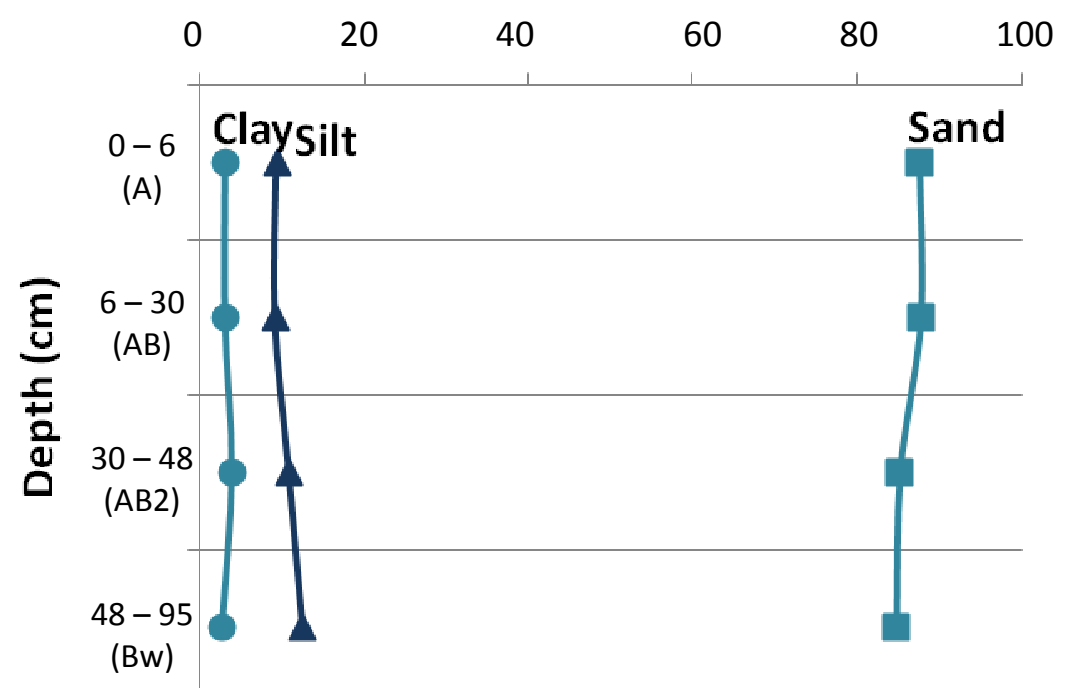

Figure 18: Particle Size Distribution of the Footslope Pit from the O Moraine 
The particle size analysis of the $\mathrm{M}$ moraine soils also showed sand as the dominant size class and mostly fine sand. There is little clay in any of the pits (Tables 18 $-23)$. The texture in all the pits is loamy sand to sand. The pits on the M moraine also show silt translocation (Figs 19 - 21); the presence of ash layers in the backslope pit forms the "silt bulge". The $\mathrm{pH}$ ranged from 5.2 to 5.7. The grayish (2Cox1b) and pinkish (2Cox2b) layers in the backslope pit tested positive for ash ( $\mathrm{NaF} \mathrm{pH}$ test) rising to a $\mathrm{pH}$ of 10.06 and 10.33 respectively within the required two minutes. These two horizons were selected for further ash testing. The horizons above and below these two layers tested negative for ash. These soils are also classified as Andic Haplocryepts.

The two possible tephra in the backslope pit were analyzed to determine origin and age at Washington State University by Franklin "Nick" Foit, an expert in tephrachronology (Foit, written communication 2011). Neither sampled was similar to Mount St. Helens ash, the most common the region, and were determined to originate from Mount Hood. The tephra sample higher in the profile $(2 \mathrm{Coxb} ; 36-40 \mathrm{~cm})$ included different glass components, one of which exhibited a strong similarity with the Zig Zag tephra (383 BP) mixed with other ashes. The tephra sample lower in the profile (3Coxb; 40-51cm) lacked multiple glass components and was similar to a Sandy River Delta ash sample. No date was available for the lower ash unit that presumably predates the ash unit above it in the soil profile. 
Table 18: Lab Soil Characteristics of the Shoulder Pit from the M Moraine

\begin{tabular}{|l|c|c|c|c|c|c|c|}
\hline Horizon & $\begin{array}{c}\text { Depth } \\
(\mathrm{cm})\end{array}$ & $\begin{array}{c}\mathrm{pH} \\
(1: 1)\end{array}$ & Texture & $\begin{array}{c}\text { Gravel } \\
(\%)\end{array}$ & Sand (\%) & Silt (\%) & Clay (\%) \\
\hline $\mathrm{A}$ & $0-5$ & 5.2 & Loamy Sand & 8 & 86 & 10 & 4 \\
\hline $\mathrm{AB}$ & $5-55$ & 5.4 & Loamy Sand & 2 & 83 & 14 & 3 \\
\hline $\mathrm{Bw}$ & $55-100+$ & 5.5 & Loamy Sand & 8 & 84 & 13 & 3 \\
\hline
\end{tabular}

Table 19: Sand Particle Size Distribution of the Shoulder Pit from the M Moraine

\begin{tabular}{|l|c|c|c|c|c|c|}
\hline Horizon & Depth $(\mathrm{cm})$ & $\begin{array}{c}\text { Very Coarse } \\
(\%)\end{array}$ & $\begin{array}{c}\text { Coarse } \\
(\%)\end{array}$ & $\begin{array}{c}\text { Medium } \\
(\%)\end{array}$ & Fine (\%) & $\begin{array}{c}\text { Very Fine } \\
(\%)\end{array}$ \\
\hline $\mathrm{A}$ & $0-5$ & 4 & 7 & 21 & 37 & 13 \\
\hline $\mathrm{AB}$ & $5-55$ & 2 & 7 & 17 & 39 & 16 \\
\hline $\mathrm{Bw}$ & $55-100+$ & 6 & 8 & 16 & 32 & 20 \\
\hline
\end{tabular}

\section{Particle Size Distribution (\%)}

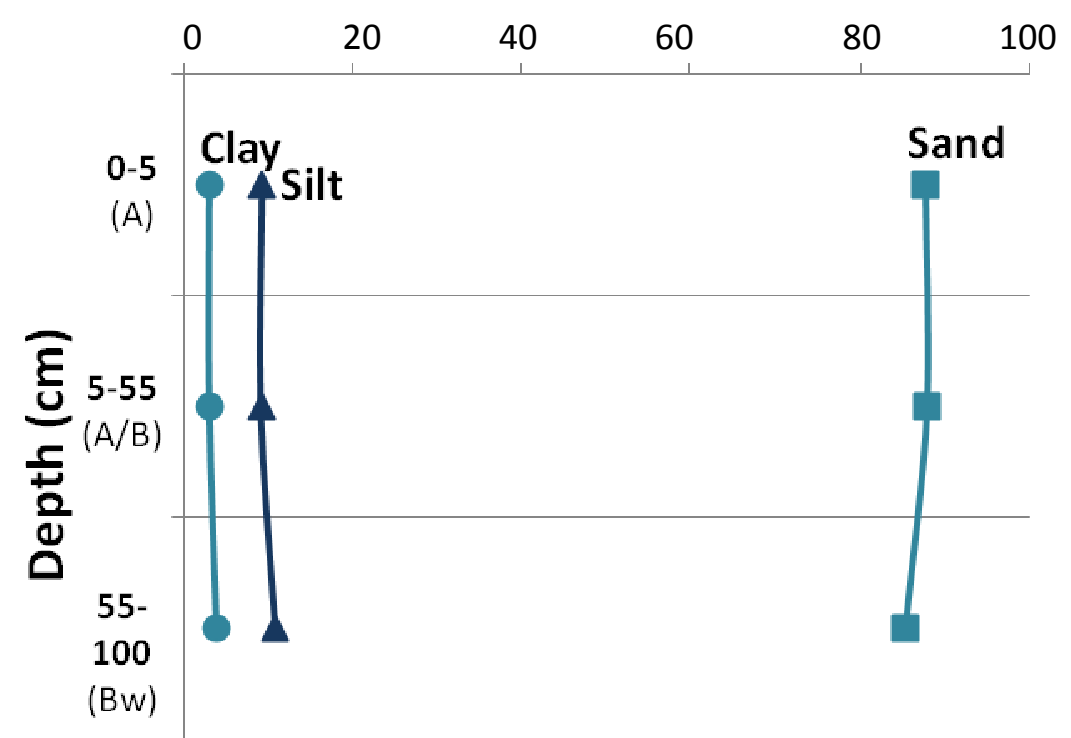

Figure 19: Particle Size Distribution of the Shoulder Pit from the M Moraine 
Table 20: Lab Soil Characteristics of the Backslope Pit from the M Moraine

\begin{tabular}{|l|c|c|c|c|c|c|c|}
\hline Horizon & $\begin{array}{c}\text { Depth } \\
(\mathrm{cm})\end{array}$ & $\begin{array}{c}\mathrm{pH} \\
(1: 1)\end{array}$ & Texture & $\begin{array}{c}\text { Gravel } \\
(\%)\end{array}$ & Sand (\%) & Silt (\%) & Clay (\%) \\
\hline A & $0-5$ & 5.3 & Sand & 5 & 89 & 8 & 3 \\
\hline AB & $5-36$ & 5.3 & Sand & 2 & 88 & 9 & 3 \\
\hline 2Cox1b & $36-40$ & 5.7 & Sandy Loam & 1 & 70 & 27 & 3 \\
\hline 2Cox2b & $40-51$ & 5.3 & Sandy Loam & 1 & 61 & 35 & 4 \\
\hline 3Bwb & $51-100+$ & 5.6 & Loamy Sand & 5 & 86 & 12 & 2 \\
\hline
\end{tabular}

Table 21: Sand Particle Size Distribution of the Backslope Pit from the M Moraine

\begin{tabular}{|l|c|c|c|c|c|c|}
\hline Horizon & Depth $(\mathrm{cm})$ & $\begin{array}{c}\text { Very Coarse } \\
(\%)\end{array}$ & $\begin{array}{c}\text { Coarse } \\
(\%)\end{array}$ & $\begin{array}{c}\text { Medium } \\
(\%)\end{array}$ & Fine (\%) & $\begin{array}{c}\text { Very Fine } \\
(\%)\end{array}$ \\
\hline A & $0-5$ & 2 & 5 & 17 & 44 & 15 \\
\hline AB & $5-36$ & 1 & 4 & 18 & 44 & 20 \\
\hline 2Cox1b & $36-40$ & 1 & 3 & 11 & 29 & 24 \\
\hline 2Cox2b & $40-51$ & 1 & 2 & 6 & 31 & 17 \\
\hline 3 Bwb & $51-100+$ & 2 & 5 & 16 & 41 & 21 \\
\hline
\end{tabular}

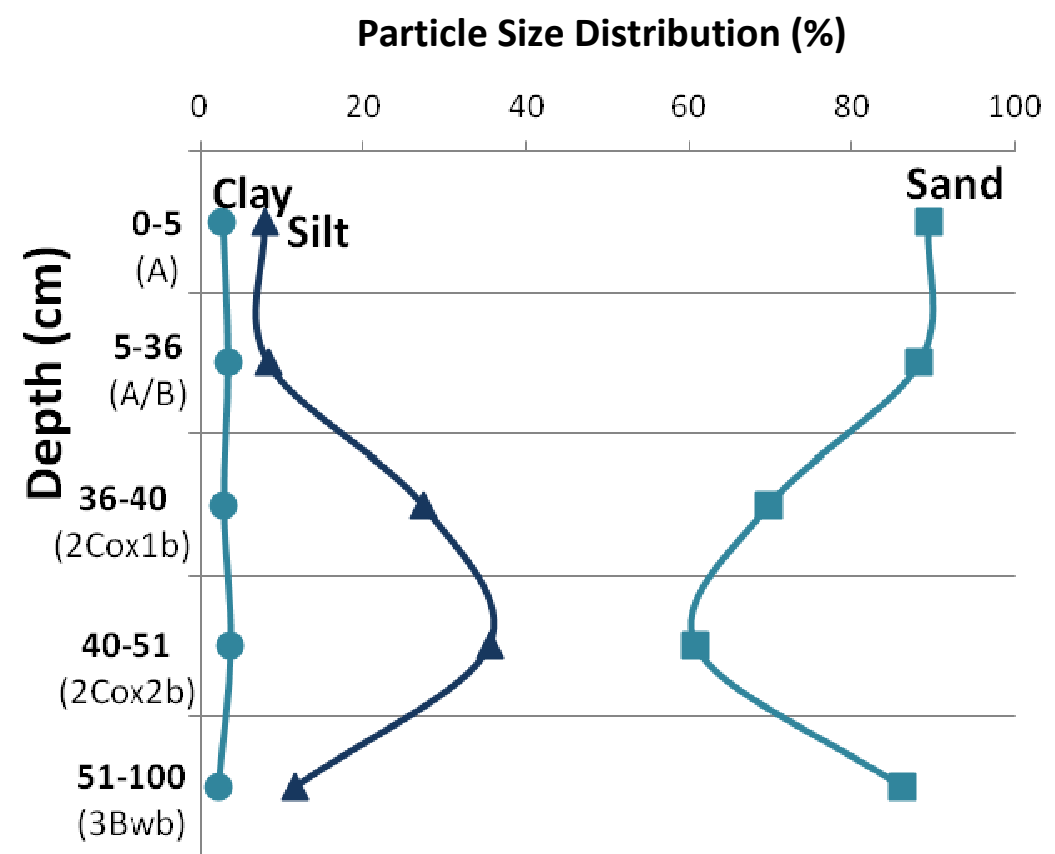

Figure 20: Particle Size Distribution of the Backslope Pit from the M Moraine 
Table 22: Lab Soil Characteristics of the Footslope Pit from the M Moraine

\begin{tabular}{|l|c|c|c|c|c|c|c|}
\hline Horizon & $\begin{array}{c}\text { Depth } \\
(\mathrm{cm})\end{array}$ & $\begin{array}{c}\mathrm{pH} \\
(1: 1)\end{array}$ & Texture & $\begin{array}{c}\text { Gravel } \\
(\%)\end{array}$ & Sand (\%) & Silt (\%) & Clay (\%) \\
\hline A & $0-21$ & 5.2 & Sand & 10 & 88 & 9 & 3 \\
\hline Bw1 & $21-40$ & 5.3 & Sand & 8 & 90 & 8 & 2 \\
\hline Bw2 & $40-90+$ & 5.3 & Sand & 10 & 87 & 10 & 3 \\
\hline
\end{tabular}

Table 23: Sand Particle Size Distribution of the Footslope Pit from the M Moraine

\begin{tabular}{|l|c|c|c|c|c|c|}
\hline Horizon & Depth $(\mathrm{cm})$ & $\begin{array}{c}\text { Very Coarse } \\
(\%)\end{array}$ & $\begin{array}{c}\text { Coarse } \\
(\%)\end{array}$ & $\begin{array}{c}\text { Medium } \\
(\%)\end{array}$ & Fine (\%) & $\begin{array}{c}\text { Very Fine } \\
(\%)\end{array}$ \\
\hline A & $0-21$ & 3 & 8 & 21 & 37 & 18 \\
\hline Bw1 & $21-40$ & 3 & 8 & 22 & 40 & 15 \\
\hline Bw2 & $40-90+$ & 3 & 7 & 19 & 38 & 19 \\
\hline
\end{tabular}

Particle Size Distribution (\%)

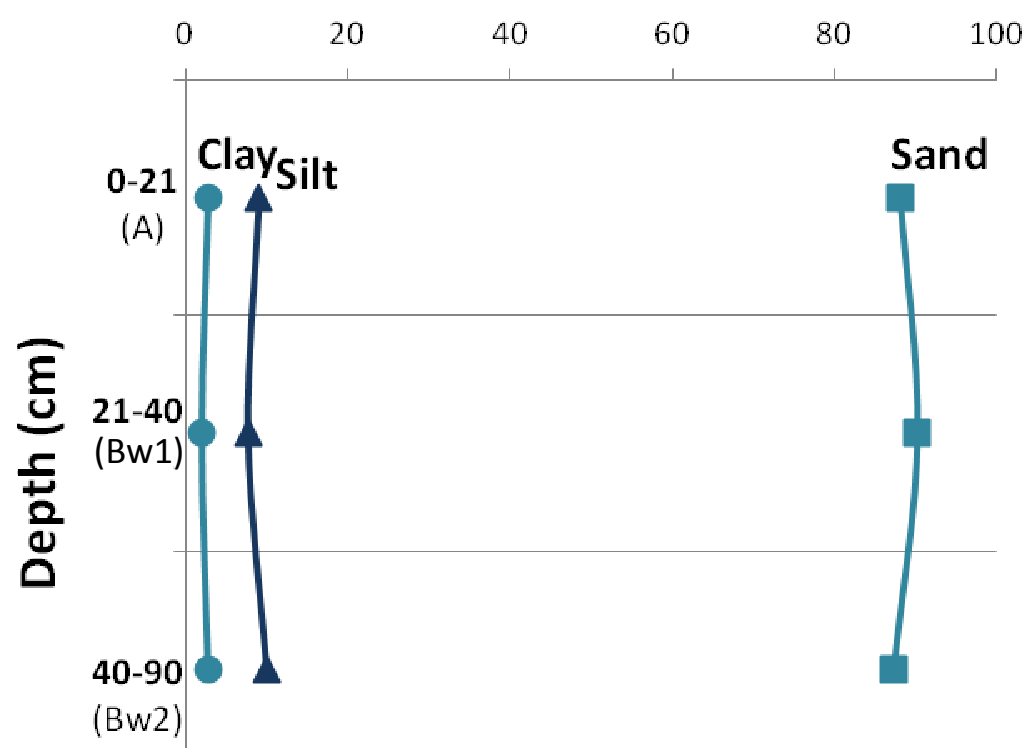

Figure 21: Particle Size Distribution of the Footslope Pit from the M Moraine 
The weak horizon differences found in the LIA moraine were consistent with the results of the particle size analysis. All the pits were almost entirely sand with only slight differences between the $A$ and $C$ horizons (Tables $24-29$, Figs $22-24$ ). Fine sand was the major component of the sand size class. The texture in all the pits was sand. The $\mathrm{pH}$ in the soil varied from 5.2 to 5.4 , with no evidence of silt translocation or ash layers. These soils are classified as Andic Cryopsamments. As before, andic indicates that volcanic products make up a portion of the soil. Cryo- refers to the cold formative environment. The -psamm- portion refers to high sand content of this soil. The -ent refers to the primary classification of the soil as an Entisol, a poorly developed and likely young soil with an $\mathrm{A} / \mathrm{C}$ profile. 
Table 24: Lab Soil Characteristics of the Shoulder Pit from the LIA Moraine

\begin{tabular}{|l|c|c|c|c|c|c|c|}
\hline Horizon & $\begin{array}{c}\text { Depth } \\
(\mathrm{cm})\end{array}$ & $\begin{array}{c}\mathrm{pH} \\
(1: 1)\end{array}$ & Texture & $\begin{array}{c}\text { Gravel } \\
(\%)\end{array}$ & Sand (\%) & Silt (\%) & Clay (\%) \\
\hline A & $0-10$ & 5.2 & Sand & 4 & 87 & 11 & 2 \\
\hline C & $10-50+$ & 5.4 & Sand & 7 & 92 & 6 & 2 \\
\hline
\end{tabular}

Table 25: Sand Particle Size Distribution of the Shoulder Pit from the LIA Moraine

\begin{tabular}{|l|c|c|c|c|c|c|}
\hline Horizon & Depth (cm) & $\begin{array}{c}\text { Very Coarse } \\
(\%)\end{array}$ & $\begin{array}{c}\text { Coarse } \\
(\%)\end{array}$ & $\begin{array}{c}\text { Medium } \\
(\%)\end{array}$ & Fine (\%) & $\begin{array}{c}\text { Very Fine } \\
(\%)\end{array}$ \\
\hline A & $0-10$ & 2 & 7 & 19 & 38 & 17 \\
\hline C & $10-50+$ & 3 & 7 & 23 & 44 & 14 \\
\hline
\end{tabular}

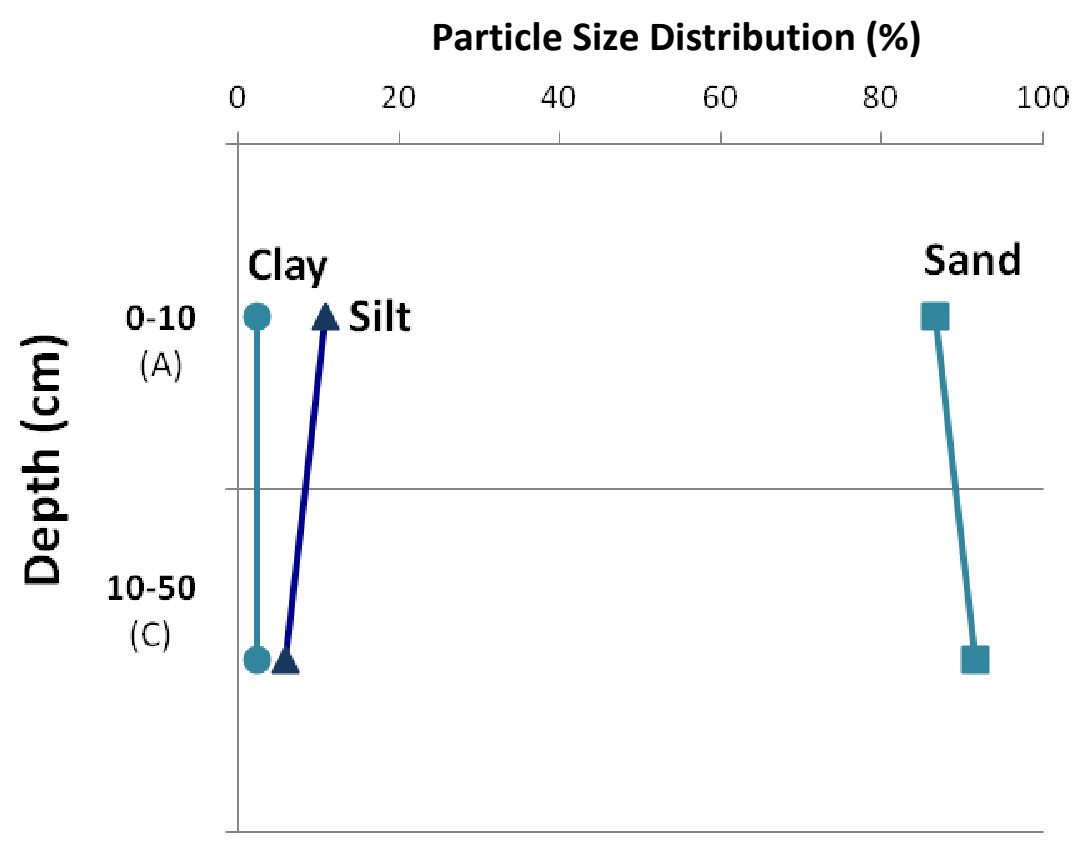

Figure 22: Particle Size Distribution of the Shoulder Pit from the LIA Moraine 
Table 26: Lab Soil Characteristics of the Backslope Pit from the LIA Moraine

\begin{tabular}{|l|c|c|c|c|c|c|c|}
\hline Horizon & $\begin{array}{c}\text { Depth } \\
(\mathrm{cm})\end{array}$ & $\begin{array}{c}\mathrm{pH} \\
(1: 1)\end{array}$ & Texture & $\begin{array}{c}\text { Gravel } \\
(\%)\end{array}$ & Sand (\%) & Silt (\%) & Clay (\%) \\
\hline A & $0-3$ & 5.2 & Sand & 4 & 91 & 6 & 3 \\
\hline C & $3-50+$ & 5.3 & Sand & 4 & 93 & 5 & 2 \\
\hline
\end{tabular}

Table 27: Sand Particle Size Distribution of the Backslope Pit from the LIA Moraine

\begin{tabular}{|l|c|c|c|c|c|c|}
\hline Horizon & Depth (cm) & $\begin{array}{c}\text { Very Coarse } \\
(\%)\end{array}$ & $\begin{array}{c}\text { Coarse } \\
(\%)\end{array}$ & $\begin{array}{c}\text { Medium } \\
(\%)\end{array}$ & Fine (\%) & $\begin{array}{c}\text { Very Fine } \\
(\%)\end{array}$ \\
\hline A & $0-3$ & 3 & 10 & 26 & 36 & 15 \\
\hline C & $3-50+$ & 1 & 7 & 3 & 39 & 10 \\
\hline
\end{tabular}

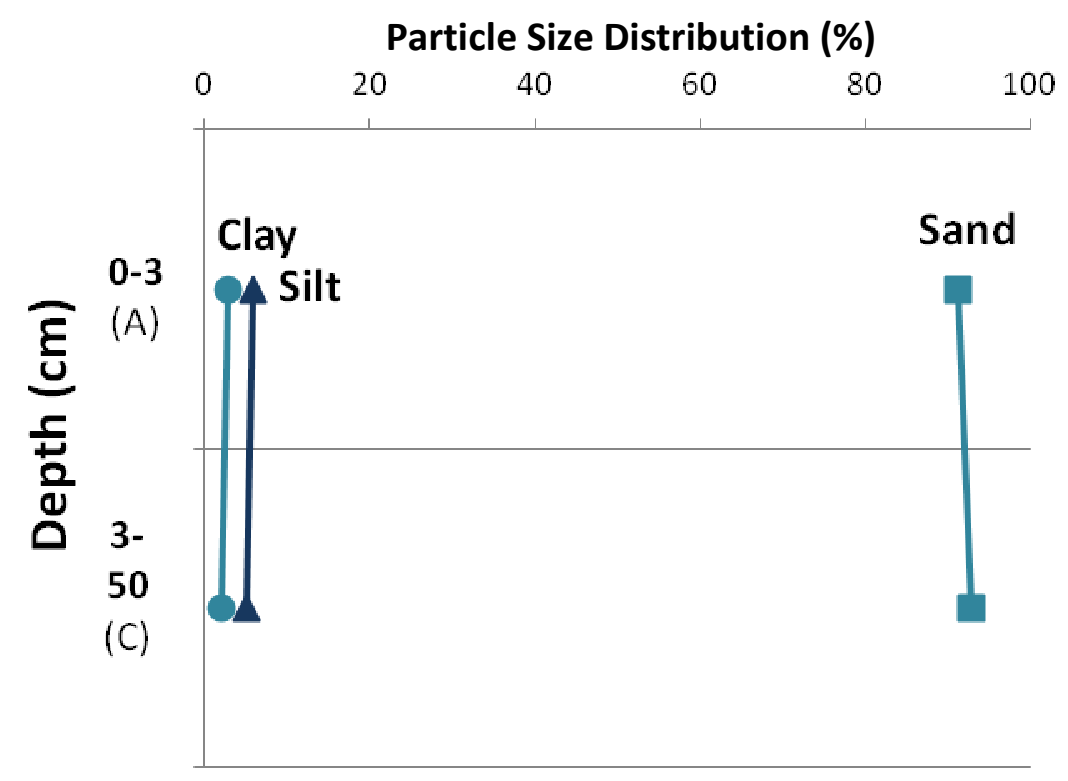

Figure 23: Particle Size Distribution of the Backslope Pit from the LIA Moraine 
Table 28: Lab Soil Characteristics of the Footslope Pit from the LIA Moraine

\begin{tabular}{|l|c|c|c|c|c|c|c|}
\hline Horizon & $\begin{array}{c}\text { Depth } \\
(\mathrm{cm})\end{array}$ & $\begin{array}{c}\mathrm{pH} \\
(1: 1)\end{array}$ & Texture & $\begin{array}{c}\text { Gravel } \\
(\%)\end{array}$ & Sand (\%) & Silt (\%) & Clay (\%) \\
\hline $\mathrm{A}$ & $0-8$ & 5.2 & Sand & 2 & 89 & 8 & 3 \\
\hline $\mathrm{C}$ & $8-50+$ & 5.4 & Sand & 16 & 90 & 7 & 3 \\
\hline
\end{tabular}

Table 29: Sand Particle Size Distribution of the Footslope Pit from the LIA Moraine

\begin{tabular}{|l|c|c|c|c|c|c|}
\hline Horizon & Depth (cm) & $\begin{array}{c}\text { Very Coarse } \\
(\%)\end{array}$ & $\begin{array}{c}\text { Coarse } \\
(\%)\end{array}$ & $\begin{array}{c}\text { Medium } \\
(\%)\end{array}$ & Fine (\%) & $\begin{array}{c}\text { Very Fine } \\
(\%)\end{array}$ \\
\hline A & $0-8$ & 2 & 7 & 23 & 39 & 18 \\
\hline C & $8-50+$ & 7 & 14 & 27 & 29 & 11 \\
\hline
\end{tabular}

Particle Size Distribution (\%)

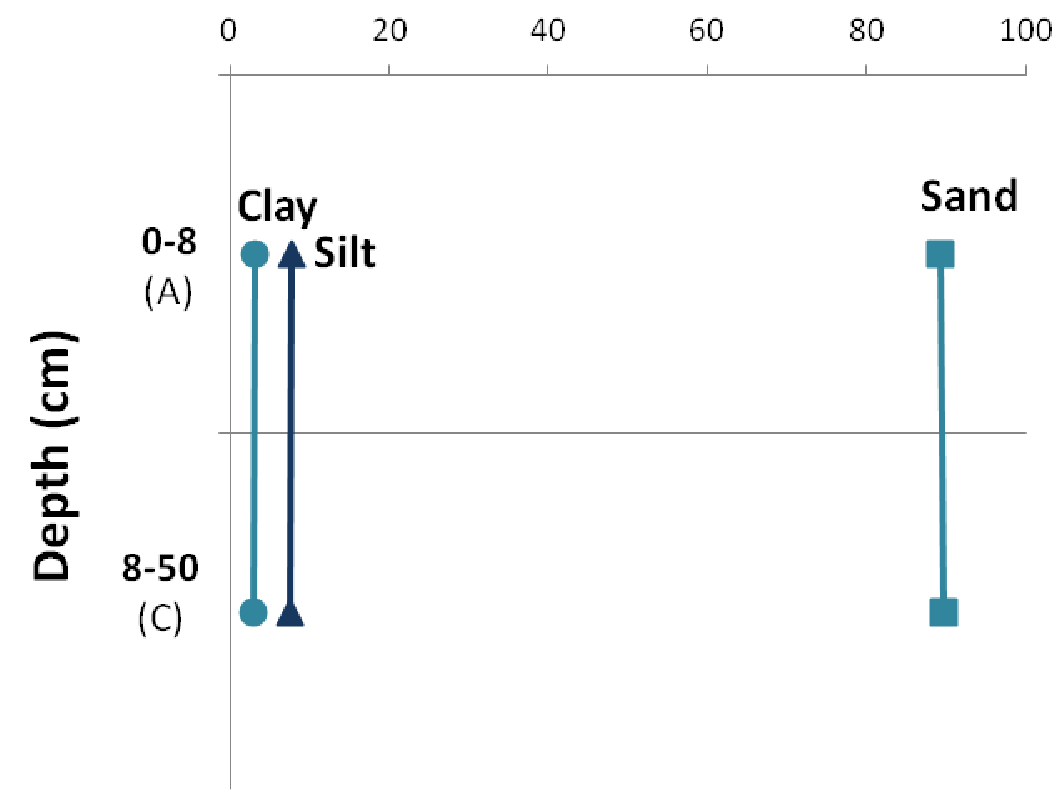

Figure 24: Particle Size Distribution of the Footslope Pit from the LIA Moraine 


\section{DISCUSSION}

Field and lab results indicate soil development of the LIA moraine is considerably less than and presumably younger than the $\mathrm{O}$ and $\mathrm{M}$ moraines. Particle size distribution and the color development in the LIA pits did not change with depth. These soils also lacked a B horizon. Therefore, these soils are Entisols, specifically Andic Cryopsamments. Given that the adjacent features are at the same elevation and are experiencing similar soil forming factors, the lack of soil development on the LIA moraine suggests that this feature likely dates to the most recent glacial advance, the Little Ice Age. The sparse vegetation also suggests an early stage of development relative to the $\mathrm{O}$ and $\mathrm{M}$ moraines. The presence of whitebark pine as one of the few tree species, scattered scrub, and scarce grasses and other ground cover support the idea that this feature only recently stabilized.

The dynamic nature and instability of this feature can be seen in the observation of an aerial photography reference point, a large boulder with an " $A$ " spray-painted on it. In previous studies on Eliot Glacier this boulder was on top of the LIA moraine (Lillquist and Walker, 2006; Jackson, 2007). During the investigation for this study in 2010, the boulder was observed on its side at the bottom of the moraine. All of these observations point the fact that this moraine is still actively settling and provides an unstable environment for soil forming processes. 
The $O$ and $M$ moraines have similar horizon sequences $(A, A B, B w)$ developed on similar parent material. The difference between the $\mathrm{O}$ and $\mathrm{M}$ moraines can be seen in the relative difference in color development and horizon depths. The A horizons in the $\mathrm{M}$ moraine are thinner than those on the $\mathrm{O}$ moraine. The Bw horizons of the $\mathrm{O}$ moraine also exhibit a wider range of color development ( $2.5 Y 5 / 3$ to $2.5 Y 6 / 4)$ than the $M$ moraines (2.5Y 5/3 and 5/2). All the soils are Inceptisols and are classified as Andic Haplocryepts.

The presence of the ash layers in the M moraine also separates it in age from the O moraine, which lacks ash layers. The silt-rich horizon in the shoulder pit on the $\mathrm{O}$ moraine tested negative for ash and none of the other horizons in any of the pits show characteristics of high ash content. The lack of any ash on the LIA moraine suggests this moraine post-dates the ash deposit. The distal position of the $\mathrm{O}$ moraine relative to the glacier indicated earlier development relative to the $\mathrm{M}$ moraine. The absence of ash on the outer moraine can only be explained by invoking several processes. Assuming the ashes were deposited on the surface of the $\mathrm{O}$ moraine some of it may have moved down the profile via silt translocation. The absence of ash-rich horizons in the $\mathrm{O}$ moraine pits suggests this process resulted in diffusion of any ash throughout the profile to concentrations too small to be detected by the $\mathrm{NaF}$ pH test.

The ash horizons in the $\mathrm{M}$ moraine backslope pit are $36-51 \mathrm{~cm}$ deep with a diffuse boundary between the upper and lower layer of ash and color differences. The upper horizon exhibits evidence of mixing and multiple glass components (Foit, 2011). 
The lower layer of ash has an abrupt boundary with the horizon below and shows little mixing. When tested for origin and age, the ash was similar to a sample collected from the Sandy River delta. No date was available to match the ash to a specific eruptive period. The platy, highly friable structure of the ash is typical of ash compressed after burial.

The confirmation of buried ash layers in M moraine suggests two possibilities. First, this feature may have been forming during an eruptive period; the ash was deposited directly on the moraine and then buried by till as the moraine continued to form. The second ash layer may have also been deposited on the moraine at a later time when this moraine was no longer active; as such, the ash translocated down as indicated by its mixed nature. Hence, this moraine formed prior to 383 YBP and based on the amount of soil development above the ash layer, it likely formed earlier than the onset of the Little Ice Age. However, the soil is less well developed than the O moraine. Thus, the $\mathrm{M}$ moraine may represent one of three regional Neoglacial glacial advances on Mount Hood intermediate between an early Neoglacial and Little Ice Age advance.

The ash layers separate the $\mathrm{M}$ moraine from the $\mathrm{O}$ moraine in age. The ash that fell was buried in the M moraine's profile becoming a distinct layer. The second ash layer fell on the inactive moraine and moved down the profile stopping only because it met the platy deposit of the previous ash. On the $\mathrm{O}$ moraine, both ash layers likely fell on the surface and either washed away or moved down the profile as silt-sized particles, through translocation, mixing with the horizons along the way. This likely created the 
"silt bulge" shown in the $\mathrm{O}$ moraine profiles. The $\mathrm{O}$ moraine, lacking an ash horizon, likely formed in between eruptive periods.

The soils on the $\mathrm{O}$ moraine are not developed enough to date to the end of the Last Glacial Maximum (12,000 YBP) or before the Parkdale eruptive period (7,700 YBP). Another climatic event that limits the age of this feature is the Climatic Optimum $(7,500$ $-5,500$ YBP). No glaciers have been documented to this time frame because the climate was warm and dry (Burke and Birkeland, 1983). This suggests a maximum limiting age for the $\mathrm{O}$ moraine at 5,500 YBP. The next eruptive period after this date is the Timberline $(1,500)$ providing a minimum limiting age (Table 30$)$.

Table 30: Comparison of Climatic Events, Eruptive Periods, and Glacial Features

\begin{tabular}{|l|l|l|}
\hline Climate & Eruptive Period & Glacial Features \\
\hline \multirow{2}{*}{$\begin{array}{l}\text { Little Ice Age } \\
(600-150 \text { YBP })\end{array}$} & $\begin{array}{l}\text { LIA Moraine } \\
(600-150 \text { YBP })\end{array}$ \\
\cline { 2 - 3 } & Old Maid (200 YBP) & M Moraine (1,500 YBP) \\
\hline & Timberline (1,500 YBP) & $\begin{array}{l}\text { F Moraine } \\
(5,500->1,500 \text { YBP })\end{array}$ \\
\hline $\begin{array}{l}\text { Climatic Optimum - } \\
\text { No glaciers } \\
(7,500-5,500 \text { YBP })\end{array}$ & & \\
\hline & $\begin{array}{l}\text { Parkdale (and Mazama ash) } \\
(7,700 \text { YBP })\end{array}$ & \\
\hline
\end{tabular}

The $\mathrm{M}$ moraine, based on position, is younger than the $\mathrm{O}$ moraine and older than the LIA moraine. The presence of a buried ash horizon indicates that this feature was active during an eruptive period. The Timberline eruptive period is the only event to fall 
between the proposed dates of the $\mathrm{O}$ moraine and LIA moraine. The ash from this event likely created the lower ash layer in the backslope pit. Any ash that fell subsequently would have moved down through the profile as a result of silt translocation, similar to the observations on the $\mathrm{O}$ moraine. This is what created the upper ash layer that showed mixing and multiple glass components. Since the $\mathrm{O}$ moraine must have formed and then been abandoned by its glacier before the $\mathrm{M}$ moraine could be formed by an advancing glacier, the minimum limiting age for the $\mathrm{M}$ moraine is older than 1,500 YBP (Table 30).

The distinct differences in the soils on these three features separate them in age. This evidence refutes the hypothesis that these features represent recessional moraines from one glacial event. If these features did represent a long term glacial event, it would suggest that the same body of ice was present for over 5,000 years, retreating and stagnating, to form the series of lateral moraines investigated here. This is not supported by the climatic history or the glacial chronologies documented on other mountains in Cascades as well as other ranges in the continental United States (Table 1). 


\section{CONCLUSIONS}

The history of Holocene glaciations on Mount Hood relies on establishing the relative ages of glacial landforms. By doing so, Mount Hood glaciation can be placed in a regional context and compared with other studies to correlate the timing of glacial episodes. Three Neoglacial moraines were sampled to the east of Eliot Glacier using catenas on the distal slopes.

Based primarily on color and particle size distribution, the soils on the LIA moraine indicate that this is a young feature, likely dated to the most recent glacial advance, the Little Ice Age (150 - 600 YBP). The instability of this feature evidenced by poorly developed soils (A/C profiles with Andic Cryopsamment classification), and sparse vegetation. This indicates a significant difference in age between this feature and the other two moraines.

Relative positioning indicates a difference in age between the two older moraines. The soil sequence of the two moraines is similar, but the $\mathrm{O}$ moraine is older and has deeper, more well-developed horizons as indicated by color. The $\mathrm{M}$ moraine has shallower horizons, but shows similar development (Andic Haplocryept) to the $\mathrm{O}$ moraine. These observations suggest these features are experiencing the same history of soil development, but are at different points along the timeline. Both backslope soils showed silt translocation in these soils with mainly a loamy sand texture. 
The evidence presented here supports my contention of three Holocene glaciations. Previous research establishes a Little Ice Age glacial advance across the western United States. The Eliot Glacial LIA moraine abuts the current glacier similar to other Little Ice Age moraines.

The differences between the $\mathrm{O}$ and $\mathrm{M}$ moraines help to refine the established chronology of glacial advances in the Cascades, which currently includes a period of glacial activity from 2,000 - 4,000 YBP. On Mount Hood, this chronology can be narrowed to three distinct episodes of glacial activity since the Climatic Optimum. The findings on the $\mathrm{M}$ moraine raise questions about the lack of an intermediary glacial period in other Cascade Mountains that is otherwise so evident in other mountain ranges.

\section{Future Work}

The soils on the $\mathrm{O}$ and $\mathrm{M}$ moraines extend deeper than originally expected suggesting the need for additional pits extending to greater depths. Differences between the $\mathrm{M}$ and $\mathrm{O}$ moraines should be investigated further, including further lab tests for organic matter and bulk density. If possible, cosmogenic radionuclide dating methods could yield more definitive results on the ages of these features. This same work should also be applied to the features on the other side of the glacier to assess similarities and differences in development. There is also a need for more detailed analyses and dating of Mount Hood tephras, including the Sandy River sample, and vegetation analysis including lichenometry. 


\section{REFERENCES}

Alexander, M.J. 1986. Micro-scale soil variability along a short moraine ridge at Okstindan, northern Norway. Geoderma 31: 341 - 360.

Allen, C.E. and S.F. Burns. 2000. Characterization of alpine soils, Eagle Cap, Wallowa Mountains, Oregon. Physical Geography 21(3): $212-222$.

Beget, J.E. 1981. Early Holocene glacier advance in the North Cascade Range, Washington. Geology 11: $389-393$.

Beget, J.E. 1984. Tephrachronology of Late Wisconsin deglaciation and Holocene glacier fluctuations near Glacier Peak, North Cascade Range, Washington. Quaternary Research 21: $304-316$.

Benedict, J.B. 1967. Recent glacial history of an alpine area in the Colorado Front Range, USA. I. Establishing a lichen-growth curve. Journal of Glaciology 6: 817 - 832.

Benedict, J.B. 1973. Chronology of cirque glaciation, Colorado Front Range. Quaternary Research 3: $584-599$.

Benedict, J.B. 1981. The Fourth of July Valley: Glacial Geology and Archeology of the Timberline Ecotone. Center for Mountain Archeology, Research Report No. 2. Ward, Colorado.

Benedict, J.B. 1985. Arapaho Pass: Glacial Geology and Archeology at the Crest of the Colorado Front Range. Center for Mountain Archeology, Research Report No. 3. Ward, Colorado.

Birkeland, P.W. 1973. Use of relative age-dating methods in a stratigraphic study of rock glacier deposits, Mt. Sopris, Colorado. Arctic and Alpine Research 5(4): 401 - 416. 
Birkeland, P.W. and R.M. Burke. 1988. Soil catena chronosequences on eastern Sierra Nevada Moraines, California, USA. Arctic and Alpine Research 20(4): $473-484$.

Birkeland, P.W., M.E. Berry, and D.K. Swanson. 1991. Use of soil catena field data for estimating relative ages of moraines. Geology 19: $281-283$.

Birkeland, P.W. 1999. Soils and Geomorphology, $3^{\text {rd }}$ ed. Oxford University Press, New York, NY.

Burke, R.M. 1978. Comparison of relative age dating (RAD) data from eastern Sierra Nevada cirque deposits with those from the tephrachronologically age controlled deposits of the Wallowa Mountains, Oregon. Geological Society of America, Abstracts with Programs 10: 211.

Burke, R.M. and Birkeland, P.W. 1983. Holocene glaciation in the mountain ranges of the western United States. In Late Quaternary Environments of the United States, Vol. 2, The Holocene, ed. Wright, H.E., Jr., pp 3 - 11. University of Minnesota Press, Minneapolis, MN.

Burt, R. (editor), 2004. Soil Survey Laboratory Methods Manual. Soil Survey Investigations Report No. 42. Ver. 4.0. Lincoln, NE.

Clark, D.H. and Gillespie, A.R. 1997. Timing and significance of late-glacial and Holocene cirque glaciation in the Sierra Nevada, California. Quaternary International 38/39: 21 -38 .

Crandell, D.R. 1980. Recent Eruptive History of Mount Hood, Oregon, and Potential Hazards from Future Eruptions. US Geological Survey Bulletin 1492.

Crandall, D.R. and Miller, R.D. 1964. Post-Hypsithermal glacier advances at Mount Rainier, Washington. U.S. Geological Survey Professional Paper 501-D, D110 - D114. 
Dahms, D.E. 2002. Glacial Stratigraphy of Stough Creek Basin, Wind River Range, Wyoming. Geomorphology 42: $59-83$.

Dahms, D.E., P.W. Birkeland, R.R. Shroba, C.D. Miller, and R. Kihl. 2010. Latest Quaternary glacial and periglacial stratigraphy, Wind River Range, Wyoming. Geological Society of America Digital Map and Chart Series 7: 46.

Davis, P.T. 1982. Chronology of Holocene glaciation, Arapaho cirque, Colorado Front Range, USA. Abstracts, XI Congress of the International Union for Quaternary Research, Moscow, USSR 2: 54.

Davis, P. Thompson. 1988. Holocene Glacier Fluctuations in the American Cordillera. Quaternary Science Reviews 7: 129 - 157.

Davis, P.T. and Waterman, S.E. 1979. New radiocarbon ages for type Triple Lakes moraines, Arapaho cirque, Colorado Front Range. Geological Society of America, Abstracts with Programs 11: 270.

Fields, M. and K.W. Perrott. 1966. The nature of allophone in soils, part 3 - rapid field and laboratory test for allophone. New Zealand Journal of Science. 9: 623 - 629.

Foit, F.F. (Nick). Written Communication, Letter to author. December 22 ${ }^{\text {nd }}, 2011$.

Gee, G. W., and J. W. Bauder. 1986. Particle-size Analysis. In Methods of soil analysis, Part 1, Physical and mineralogical methods, $2^{\text {nd }}$ Edition, Agronomy Monograph 9, ed. A.L.Page, pp 383 - 411. American Society of Agronomy, Madison, WI.

Haugland, J.E. and S.F. Burns. 2006. Soils and geomorphology in the Oregon Cascades: A comparative study of Illinoian-aged and Wisconsin-aged moraines. Physical Geography 27(4): $363-377$.

Jackson, K.M. 2007. Spatial and Morphological Change on Eliot Glacier, Mount Hood, Oregon. Thesis, Portland State University, Portland, OR. 
Jenny, H. 1941. Factors of Soil Formation. McGraw-Hill, New York, NY.

Kiver, E.P. 1974. Holocene glaciation in the Wallowa Mountains, Oregon. In Quaternary Environments: Proceedings of a Symposium, ed. W.C. Mahaney, pp 169-96. Geographical Monographs No. 5. York University, Toronto, Canada.

Konrad, S. K. and Clark, D.H. 1998. Evidence for an early Neoglacial glacier advance from rock glaciers and lake sediments in the Sierra Nevada, California, USA. Arctic and Alpine Research 30(3): $272-284$.

Lafrenz, M.D. 2001. The Neoglacial History of Mt. Thielsen, southern Oregon Cascades. Thesis, Portland, State University.

Lillquist, K. and K. Walker. 2006. Historical glacier and climate fluctuations at Mt. Hood, Oregon. Arctic, Antarctic, and Alpine Research 38(3): $399-412$.

Lundstrom, S.C. 1993. Photogrammetric analysis of $1984-89$ surface altitude change of the partially debris-covered Eliot Glacier, Mount Hood, Oregon, USA. Annals of Glaciology 17: $167-170$.

Mahaney, W.C., B.D. Fahey, and D.T. Lloyd. 1981. Late Quaternary glacial deposits, soils, and chronology, Hell Roaring Valley, Mount Adams, Cascade Range, Washington. Arctic and Alpine Research 13(3): $339-356$.

Mahaney, W.C. and J. Spence. 1984. Glacial and periglacial sequence and floristics in Jaw Cirque, central Teton Range, western Wyoming. American Journal of Science 284(8): $1056-1081$.

Marcott, S.A., A.G. Fountain, J.E. O'Connor, P.J. Sniffen, and D.P. Diether. 2009. A latest Pleistocene and Holocene glacial history and paleoclimate reconstruction at Three Sisters and Broken Top Volcanoes, Oregon, USA. Quaternary Research 71: 181 - 189. 
McFadden, L.D. and P.L.K. Knuepfer. 1990. Soil geomorphology: the linkage of pedology and surficial processes. Geomorphology 3: 197- 205.

Miller, C.D. 1969. Chronology of Neoglacial moraines in the Dome Peak area, North Cascade Range, Washington. Arctic and Alpine Research 1:49 - 66.

Milne, G. 1935. Some suggested units of classification and mapping particular for East African soils. Soil Research 4(3): $183-198$.

Nelson, R.L. 1954. Glacial geology of the Frying Pan River Drainage, Colorado. The Journal of Geology 62(4): $325-343$.

Phillips, F. M., M. Zreda, M.A. Plummer, D. Elmore, and D.H. Clark. 2009. Glacial geology and chronology of Bishop Creek and vicinity, eastern Sierra Nevada, California. GSA Bulletin 121(7/8): $1013-1033$.

Pirot, Rachel. 2010. Initiation Zone Characterization of Debris Flows in November, 2006, Mount Hood, Oregon. Thesis, Portland State University, Portland, OR.

Reasoner, M.A., P.T. Davis, and G. Osborn. 2001. Evaluation of proposed early-Holocene advances of alpine glaciers in the North Cascade Range, Washington State, USA: constraints provided by palaeo-environmental reconstructions. The Holocene 11: $607-611$.

Scott, W.E. 1977. Quaternary glaciation and volcanism, Metolius River area, Oregon. Geological Society of America Bulletin 88: 113 - 124.

Scott, W.E. 1990. Patterns of volcanism in the Cascade Arc during the past 15,000 years. Geoscience Canada 17(3): $179-183$.

Scott, W.E., C.A. Gardner, D.R. Sherrod, R.I. Tilling, M.A. Lanphere, and R.M. Conrey. 1997. Geologic history of Mount Hood volcano, Oregon - A field trip guidebook. US Geological Survey Open-File Report 97-263. 
Sharp, R.P. 1969. Semiquantitative differentiation of glacial moraines near Convict Lake, Sierra Nevada, California. The Journal of Geology 77(1): 68 - 91.

Soil Survey Staff. 2006. Keys to Soil Taxonomy, $10^{\text {th }}$ ed. USDA, NRCS. Washington D.C.

Thouret, J.-C.2005. The stratigraphy, depositional processes, and environment of the late Pleistocene Polallie-period deposits at Mount Hood volcano, Oregon, USA. Geomorphology 70: $12-32$.

Williams, L.D. 1974. Neoglacial landforms and Neoglacial chronology of the Wallowa Mountains, northeastern Oregon. Thesis, University of Massachusetts, Amherst. 